\title{
LAW, CUSTOM AND MYTH: ASPECTS OF THE SOCIAL POSITION OF WOMEN IN CLASSICAL ATHENS
}

In memoriam E.R.D

\section{INTRODUCTION}

IT is some years now since the Oxford anthropologist Edwin Ardener in his article 'Belief and

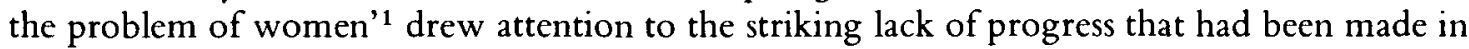
understanding traditional societies as they are seen from the point of view of women: 'the models of a society made by most ethnographers tend to be models derived from the male portion of that society'. The result, as he pointed out, is that, in considering social structure, 'we are, for practical purposes, in a male world. The study of women is on a level little higher than the study of the ducks and fowl they commonly own.' He went on to put forward an explanation of the fact, by suggesting that, since the dominant structure of society is articulated and communicated in terms of a male world-position, women constitute a 'muted group', made inarticulate by the lack of a language in which to communicate their particular sense of society and its relationship to the totality of experience.

With the society of Athens in the fifth and fourth centuries B.C. we are in much the same situation. In some respects, we might think, better off, but in one crucial point, actually worse. Better off, as we might suppose, since in the imaginative literature of classical Athens we have what seems to be a highly articulate and prominent, not marginal, presentation of women, and their role in society: in this world, it seems, women 'speak' and share the centre of attention with men. But this is a mirage: we can have no direct access to the model of Athenian society to which women subscribed, even as it might have been expressed in the dominant language of men. For the evidence available to us is almost without exception the product of men and addressed to men in a male dominated world. It takes the assumptions of the masculine order of things for granted, in a sense that goes beyond even the experience of the anthropologist in the field. We have to be quite clear about this: it is all too easy to imagine, thoughtlessly, that we are somehow in a position to look at ancient Greek society, and particularly that of fifth and fourth century Athens, from some sort of central 'ethnographic' point of vantage, from where we can see the social scene spread out before us without distortion of perspective and starting from which, warned by Ardener's observations, we can proceed to look at the world as it was seen by women. Of course I have only to say that for it to become immediately obvious that it is not so; but it does require a constant effort of thought and imagination to remember that the words of a Lysistrata or a Medea, for example, are the product of a man's imagination and addressed to men, ${ }^{2}$ and it is

This paper is a somewhat revised version of a lecture given to the Hellenic Society in London in June 1974. Earlier versions had been read at the J.A.C.T. Summer School in Ancient Greek at Cheltenham and at Aberystwyth; later versions to branch meetings of the Classical Association in Manchester, Exeter and Bristol. I was much helped by criticism and comment on all these occasions. Since 1974 the paper has enjoyed a twilight existence, circulating in samizdat form and being referred to, with permission, by Roger Just in his article in the Journal of the Anthropological Society of Oxford (vi 4 [1975] I 53-70); in turn I have had the benefit of seeing a revised version of his article. I have also gained greatly from generous help with information and criticism from Jan Bremmer, John Davies, Nick Fisher, Peter Jones, Jack Kells, Margaret Kenna, Mary Lefkowitz, Joe Loudon, Simon Pembroke and Geoffrey de Ste Croix: to all these friends and colleagues I offer warm thanks-and the usual disclaimer that they are not to be thought responsible for my views.

${ }^{1}$ Originally published in J. S. La Fontaine (ed.), The interpretation of ritual (London 1972) and reprinted in S. Ardener (ed.), Perceiving women (London 1975) I-17: refs are to this reprint. The article has become something of a classic since publication and has aroused some controversy, notably in an article by Nicole Mathicu, 'HommeCulture, Femme-Nature?', in L'Homme (July-Sept. 1973) IOI-13. Ardener replies to this and other criticism in 'The "Problem" revisited', S. Ardener op. cit. 19-27.

2 See the admirably cautious remarks of K. J. Dover, Aristophanic Comedy (London 197I) I $58 \mathrm{ff}$. But even here we have to remind ourselves that when we talk of 'the Greeks' ('the Greeks ... tended to believe that women enjoyed sexual intercourse more than men and had a lower resistance to sexual temptation'), we mean-we have to-'Greek men': in this case Hes. fr. $275 \mathrm{MW}$ ! Ar. $L \gamma$ s. I6o ff. might suggest a different view of the sexual satisfaction obtained by men and women. See also Dover, Greek Popular Morality (Oxford 1974) 95-102; Greek Homosexuality (London 1978) 87-90, 100-6, I 48-52, I $7 \mathrm{I}-84$ and $n$. 5 bclow. In using the phrase 'addressed to men' I am not trying to beg the (perennially interesting) 
absolutely essential that we make that effort, and continuously. Here then there is ground for vigilance. Of course, in a male dominated world such as the one we shall be examining, or indeed our own, it is possible that some women (perhaps even a majority) will have come to accept the assumptions that prevail among men and will have come to think of themselves as men have taught them to think (that point is indeed implicit in Ardener's description of women as 'inarticulate'): it is possible that if we could interrogate the women of classical Athens that is what we should find-but we are not, in fact, in a position to interrogate them and it is mere arrogance simply to assume it. ${ }^{3}$ It follows, then, that it is with the dominant, male model of society that we shall perforce be largely concerned here, and that is a fact of which we must remain conscious throughout this discussion.

The subject of this paper will appear positively trendy, in view of the spate of work recently produced, including two whole numbers of Arethusa (vi I [1973]; xi I-2 [1978]) devoted to the subject of women in antiquity. But I make no apology for it on that account: if one reads a sample of the better things written on this subject, from Gomme's classic essay of more than fifty years ago ${ }^{4}$ down to the most recent, I think it is fair to say that almost no progress has been made ${ }^{5}$ and that much further study is needed. But if this is so it certainly calls for some explanation. The explanation, I am quite sure, is largely a matter of methodology: the question has been put in terms that are naive and misleadingly, even grossly, over-simple. It has been put always from a male perspective, not through any explicit awareness of the determining nature of the evidence, but as though there were no other perspective, and as though to ask 'were women regarded [by men] with "contempt" or "respect"?' were a question capable of a simple 'yes' or 'no' answer, as though there were some single and univocal scale of values on which it should be possible to place 'women' as evaluated by 'men'. In these terms the question is simply unanswerable: however long we go on discussing it we shall not reach agreement. But why has the question been put in these terms?

Before we can answer that question there are two further points we should notice. The first of these is the fact recently stressed by Sarah Pomeroy, ${ }^{6}$ that different investigators have drawn on quite different, indeed mutually exclusive, categories of evidence to support their case, one group, drawing largely on myth and imaginative literature, particularly Homer and the theatre, as Gomme does; and the other on the orators of the fourth century and on the evidence of inscriptions. This curious selectivity, which is usually justified, if at all, by a priori generalisations about the 'representativeness' of the various available sets of data, is itself sufficiently striking, especially when coupled with an equally arbitrary and generally casual approach to the whole question of the juridical position of women and its implications. ${ }^{7}$ But when these facts are combined with a marked tendency to demonstrably false assertion we must begin to feel that we are faced with a question of quite peculiar methodological status. And so we are. But I had first

question of whether women formed part of the audience at the dramatic festivals: 1 would however agree with Dover (Ar. Com. i6 f.) that, whatever the actual composition of the audience, it was to male judgment and to male sensibility that fifth-century (and fourth-century) drama was addressed: for the evidence as to fact, see PickardCambridge, Dramatic Festivals of Athens ${ }^{2}$ (Oxford 1968) $263-5$.

${ }^{3}$ Moreover, of course, it is possible also that there might be a large measure of difference between overt and covert aspects of women's roles in classical Athens: compare Ernestine Friedl's analysis of modern Greek village society in her essay 'The position of women: appearance and reality', Anthrop. Q. xl (1967) 97-108; and Pierre Bourdieu's distinction between 'official' and 'unofficial' power in Kabyle society, Outline of a theory of practice (Cambridge 1977) 4I-3, 45.

${ }^{4}$ CPh xx (1925) 1-25, repr. Essays in Greek History and Literature (Oxford 1937) 89-115. Gomme's essay is still clearly the best starting-point for a discussion of this question: his later supporters-e.g. Post, TAPA lxxi
(1940) 420-59; Richter, CJ lxvii (1971) I-8-do not add much and are sometimes less perceptive in their treatment of the (chosen) evidence.

${ }^{5}$ I would particularly except Dover's trio of articlesBICS x (1964) 31-42; JHS lxxxvi (1966) 41-50; Arethusa vi (I 973) $59-73$ - but they are concerned more specifically with the question of sexual relations, in a more restricted sense. See also G. Devereux, Symbolae Osloenses xlii (1967) 69-92. The articles of M. Arthur, Signs ii (1976) 382-483, and N. Loraux, Arethusa xi (1978) 43-87, suggest that greater methodological sophistication is at last becoming acceptable.

6 Arethusa vi (1973) 141; cf. Goddesses, whores, wives, and slaves (London 1976) 59-60. Pomeroy's book (esp. $57-119)$ is an important contribution to discussion of women's roles in classical Athens.

${ }^{7}$ Even in one of the more sophisticated and perceptive of earlier studies, J. Vogt's essay on sexual equality (Von der Cleichwertigkeit der Geschlechter in der bürgerlichen Gesellschaft der Griechen, AAW Mainz 1960, no. 2, 7-8): less than one page out of forty-three. 
perhaps best try to substantiate my claim that demonstrably false assertions are characteristic of this particular field of enquiry.

Two examples will have to do. The first is from Gomme's essay. Discussing the controversial (and slippery) question of 'seclusion' Gomme turns to fifth century tragedy and refers to 'the freedom with which they [women] come and go on the stage'. 'Ismene, most timid of women... does not censure Antigone (and herself) for appearing outside the gynaikonitis and still more for proposing to walk through the streets of Thebes. Neither does Medea hurry indoors when the stranger Aigeus appears, and the latter-a perfectly respectable Athenian-does not seem to expect her to. ${ }^{8}$ Quite apart from the stylisation of social life to which it could be argued that the conventions of the fifth century theatre inevitably led (I shall return to this point later), ${ }^{9}$ Gomme's assertion rather breathtakingly ignores a fair number of counter examples from tragedy itself. Consider, for example, the Teichoskopia scene of Phoenissae: the paidagogos emerges first from the palace of the Labdacidae and only after he has assured himself that there are no strange males in sight does Antigone appear, with her mother's specific permission to leave the parthenones (the girls' quarters). At the end of the sung section of the scene she returns inside, to remain 'in the girls' quarters', the paidagogos commenting this time on the approach of strange women, prone (as women) to gossip. ${ }^{10}$ In Euripides' Electra Electra's peasant husband criticises her for being seen loitering and talking to strange young males outside the house. ${ }^{11}$ Nor are these moments indicative of some special Euripidean concern with social 'realism' or of any change in social norms during the fifth century (on this last point I would agree with Gomme's effective demolition): ${ }^{12}$ in Sophocles' Electra Clytemnestra accounts to her own satisfaction for Electra's 'wandering untethered' in public view and 'bringing shame on her philoi' by the absence of Aegisthus' male control. ${ }^{13}$ Aeschylus' Eteocles orders the women of the chorus in Seven to return home with the words:

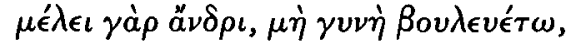

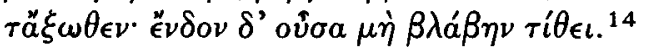

$$
\begin{aligned}
& \text { 'It is the concern of men-no place for women's schemes- } \\
& \text { what lies outside: you stay within and cause no hurt.' }
\end{aligned}
$$

And even in the case of one of Gomme's own examples, Medea, is it not reasonable to see in her

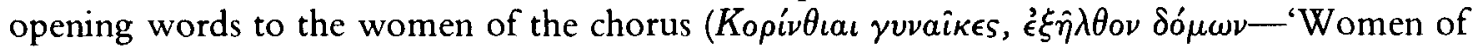
Corinth, I have come out of the house ...') some implication of conscious abnormality in what she is doing? ${ }^{15}$ It is just not true that in Attic tragedy women come and go from their houses at will'.

My second example is more open to debate: it comes from a more recent article by Prof. Le Gall. ${ }^{16}$ In the course of an interesting discussion of the relationship between social and political status as it concerns women, Le Gall asserts in passing that though women were not technically citizens and were thus not entered on the lexiarchikon grammateion of the deme, the birth of female children was declared to the phratry-members of their father. ${ }^{17}$ I find that assertion surprising. It is supported by reference to evidence assembled by Glotz-Cohen, but the passages referred to there not only do not prove the point that Le Gall is asserting, they amount to something very like proof of its converse. ${ }^{18}$ In none of them is there any reference to the presentation of daughters to

\footnotetext{
${ }^{8}$ Gomme (n. 4) 95 f. See also 98; 'in Attic tragedy women come and go from their houses at will'.

${ }^{9}$ And apart also from the fact that tragedy is as selective, and as little concerned (however differently) with 'naturalistic' ideas of continuity or consistency, in its presentation of 'social reality' as is comedy: for comedy, see for example, Dover, Ar. Com. $4 \mathrm{I} \mathrm{ff}$., $59 \mathrm{ff}$; for tragedy, PCPS xxiv (1978) 43-67, esp. 54-8. Women's literacy as presented in tragedy is well treated by F. D. Harvey, REG Ixxix (1966) $621-3$.

${ }^{10}$ Eur. Phoen. $88 \mathrm{ff}$., $193 \mathrm{ff}$.

11 Eur. El. $341 \mathrm{ff}$.

12 Gomme (n. 8).

${ }^{13}$ Soph. El. $516 \mathrm{ff}$ : compare Chrysothemis' opening

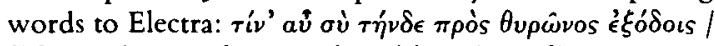

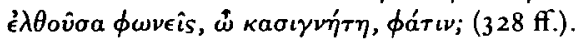


the phratry ${ }^{19}$ and in several the evident differences between the ways in which the speaker attempts to prove the legitimacy of his two parents tells strongly in favour of the conclusion that they were not presented. For example, in [Dem.] lvii $67^{20}$ Euxitheos lists as witnesses of his father's legitimacy first five of his father's male agnatic kinsmen and a number of male affines (his father's female cousins' husbands); then his father's phrateres, the Gennetai with whom he shares his Apollo Patroos and Zeus Herkeios ${ }^{21}$ and the same íía (family tombs), and his father's fellow demesmen. For his mother's legitimacy, on the other hand, he cites, as well as a similar range of male agnatic kinsmen and affines, only the phrateres and fellow demesmen of her [male] kinsmen: the conspicuous absence of reference to phrateres of his mother makes Le Gall's assertion at the least highly improbable. Again the round-about way in which the speaker of Isaeus viii sets about establishing his mother's legitimacy in contrast to the direct citation of phrateres among those who attest his own status supports the same conclusicn. ${ }^{22}$ He calls the witnesses at his mother's wedding, the phrateres of his grandfather who were present at the marriage feast, and invokes the fact that the wives of his fellow demesmen chose his mother to hold office at the Thesmophoria, ${ }^{23}$ as well as the fact that he was himself accepted into his father's phratry. In fact such indirect and informal evidence for the status of women is absolutely normal, and in the instances relied upon by Le Gall there is no evidence for the formal presentation of female children even to the phratry. ${ }^{24}$

There is one instance which might seem to support Le Gall's assertion, but it seems to have attracted little recent attention and is not referred to by Le Gall. ${ }^{25}$ It is, I would suggest, the exception that proves the rule for which I have been arguing. The speaker of Isaeus iii has been asserting throughout that the woman whose kyrios is his opponent is not the legitimate daughter of the $\gamma v \nu \dot{\eta} \dot{\epsilon} \gamma \gamma v \eta \tau \eta^{\prime}$ (betrothed wife) of Pyrrhos whose estate is the object of dispute in this case, but is vó $\theta \eta$ (not legitimate) since her mother was the pallake (woman with whom he was living) and not the wife of Pyrrhos. In ch. 73 he suddenly and belatedly produces the argument that if things had been as Xenokles, the kyrios, asserts, Pyrrhos would have been able to present and

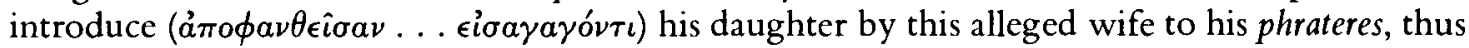
leaving her as epidikos with the whole of his estate, and could have requested his phrateres to admit

\footnotetext{
${ }^{19}$ It can hardly be argued that presentation to a phratry was somehow irrelevant to the question of the legitimacy of women: it was relevant for men, and there would be no point in the case of women in citing the evidence of the phrateres of male kinsmen if this were not a way of establishing an indirect relationship with a phratry.

${ }^{20}$ See also earlier in the same speech, 20-3, where the same witnesses are called individually.

${ }^{21}$ For the interpretation of this phrase, with its implication that Euxitheos was not a member of a genos, see Andrewes, JHS $\operatorname{lxxxi}$ (196I) $7 \mathrm{f}$., whose reconstruction of the composition and workings of a phratry seems much the most convincing on the available evidence.

22 Isae. viii 1 8-20: $c f .2$ I ff. the speaker's being allowed to bury his paternal grandfather and to contribute to the cost of the funeral as evidence of his mother's legitimacy.

${ }^{23}$ For participation in the Thesmophoria as an index of the legitimacy of women, see also Isae. iii 80 ; vi 50 .

${ }^{24} C f$. [Dem.] lvii $40-3$ : the phrateres $\tau \hat{\omega} \nu \sigma v \gamma \gamma \epsilon \nu \hat{\omega} \nu \tau \hat{\omega} \nu$ $\tau \hat{\eta} s \mu \eta \tau \rho o s s \alpha i \delta \eta \mu o \tau a i$, and the evidence of his mother's two marriages with the witnesses to the ' $\gamma \gamma v \eta^{\prime}$ and the

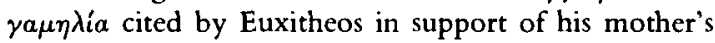
legitimacy. Contrast $46 \mathrm{ff}$. where his own status is established by calling his phrateres and by appeal to the demeregister. It is therefore hardly surprising that no female names appear in the extant phratry lists, $I G$ ii $^{2} 2344-5$; nor that the elaborate regulations of the Demotionidai (IG ï $^{2}$ I $237=$ Sokolowski LSCG I9) should be formulated throughout with reference only to male candidates and to sons. That Plato in the Laws (vi 785a) should specifically legislate for the compulsory phratry regist-
}

ration of female as well as male children is in line with his treatment of phratries as a sub-division of the deme and a part of the formal structure of the community: see Gernet, Platon: Les Lois (Budé I95 I) i p. cxiv f. ('un organisme de droit public et une subdivision de la cité); G. M. Morrow, Plato's Cretan City (Princeton I g6o) I 26-8.

${ }^{25}$ Isae. iii 73: the point is made twice more in the speech (at 76 and in the peroration, 79), so that it is not one of those typically Isaean sleight-of-hand arguments which vanish as soon as produced: this one seems intended to be thought about. Phanodemus $F G r H 325$ F I 7 (cited by Harp. s.v. $\gamma a \mu \eta \lambda i ́ a)$ tells us only that he did not (infuriat-

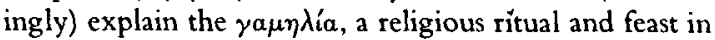
which phrateres took part, as 'the introduction of women (? wives: $\gamma v v a \iota \kappa \hat{\omega} \nu$ ) to the phrateres'. Didymus in one place did (the word used is $\epsilon i \sigma a \gamma \omega \gamma \eta^{\prime}$ ), but Harpocration found this explanation unacceptable, since Didymus cited no passage in the orators to substantiate it:

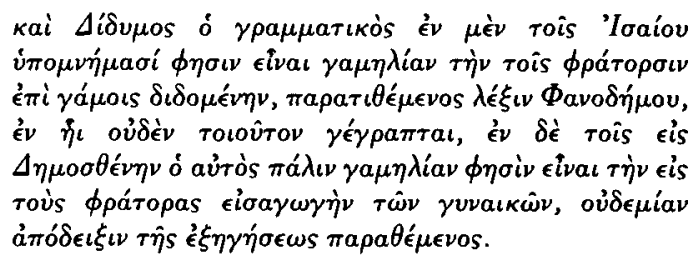

Jacoby's only reason for accepting Didymus' assertion (Comm. on Phanodemus loc. cit. FGrH iii b, suppl ii I62 n. 4 ) is that the 'action ... is . . not only credible, but even necessary to prove that the mother also comes of citizen stock'- which begs the question. 
( $\epsilon i \sigma a \gamma a \gamma \epsilon \hat{\imath} v$ ) one of the sons produced by his daughter as his (adoptive) son. The language used is that which Isaeus regularly uses elsewhere of the presentation and admission of male children to the phratry, ${ }^{26}$ but the essential point here is clearly that the daughter would be, if Xenokles is telling the truth, an epikleros, that is a female descendant of quite special significance in the transmission of family property, since it is only through her that the male line can continue and the oikos not become technically 'empty'. Thus introduction to the phratry is being presented as the only step that Pyrrhos can take, since the daughter has as yet no male offspring, in legitimating his male descendants. ${ }^{27}$ The uniqueness of the instance may be due as much to unusual circumstances (as Wyse points out, we are never told by Isaeus how old the daughter in question was at her father's death) as to Isaeus' well-known penchant for throwing sand in the eyes of juries. Nevertheless, the instance is unique: to set beside it there are only a puzzling passage in Harpocration about something which Phanodemus did not say, two schematic and muddled passages in the Lexicographers ${ }^{28}$ and a scholium on Aristophanes which looks as if it derives from the same source. ${ }^{29}$ The silence of all our other sources constitutes very much more impressive evidence and I infer that girls were not introduced to, still less registered as members of, the phratry. ${ }^{30}$

To summarise then. Discussion of the social position of women in antiquity has been characterised by over-simplification of the issues, by concentration on the part of different investigators on mutually exclusive sets of data, and by a tendency (I think it is fair to say more marked here than elsewhere) to false statement which the actual evidence is enough to rebut. If we ask why, as we must, the answer is surely clear. It is that we are dealing with a question which involves powerful and deep-seated emotional drives and in which, therefore, rationalisation plays a correspondingly large role. Part of the pleasure in reading Gomme's essay (and part of the danger in believing him) comes from our sense of the extent to which he is engaged emotionally in the quest for a satisfactory answer to the question as he puts it. But we have to be aware that the answer is going to have to satisfy emotional as well as rational requirements; and here is a second, and by far the most important ground for vigilance, for the tendency to rationalise can lead to strange conclusions. When Gomme sums up his position by saying that to the unprejudiced reader of Homer, Sappho, Alcman, Simonides and the three tragedians there is nothing 'remarkable about the position of women in Athens, except perhaps the special honour paid to them' ${ }^{11}$ I can only gasp: that seems to me a simplistic fantasy.

What I want to do is look briefly at the real complexities of the question from three points of view, in the belief that the ways in which any society defines its own structure to itself and communicates that structure to its members are likely to constitute a composite of formal and informal, of conscious and unconscious, of explicit rules and implicit norms and patterns, and that to grasp the thing with any faithfulness we need to look at more than one of these ways: the formal rules of law will tell us one thing, the half-conscious paradigms of myth perhaps another. I hope to show that my three aspects stand in a complementary relationship to each other.

${ }^{26}$ For ciór $\gamma \epsilon \iota$ of introducing male children to the phratry, see Isae. ii I 4; vi 2 I ff.; viii I 9; $x$ 8, xii 3 etc.; for ảmoфaívw, Isaeus vi 22.

27 [Dem.] xliii i 3 f, with which A. R. W. Harrison, Law of Athens i (Oxford 1968) $92 \mathrm{n}$. I, following Wyse, links the passage, makes no mention of introducing the epikleros, merely the son subsequently produced by her:

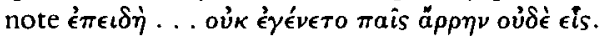

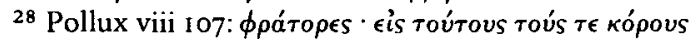

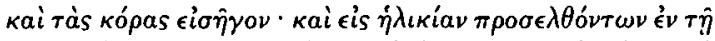

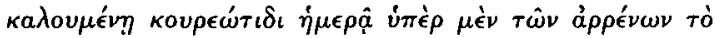

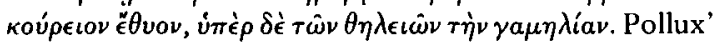
attempt to be tidy produces the wholly improbable asser-

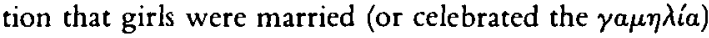
on the day appointed for boys to be admitted to the

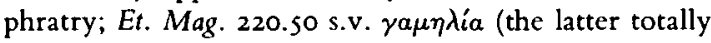
confused).

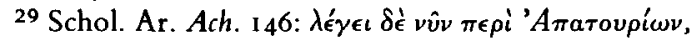

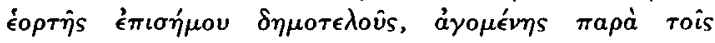

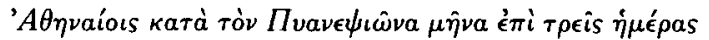

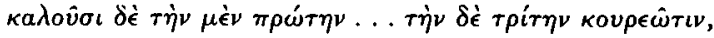

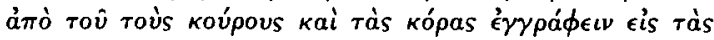
фparpias: the argument from etymology is hardly convincing, and would in any case prove nothing about girls.

${ }^{30}$ Busolt-Swoboda, Gr. Staatskunde ii $960-3$ pass over the question of the introduction of girls in a single noncommittal sentence. Wyse $(357-60,363-4)$ adduces more evidence, but comes (apparently) to no conclusion. I would suggest (pace Wyse) that Apollodorus' formula-

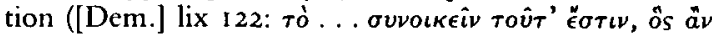

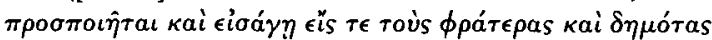

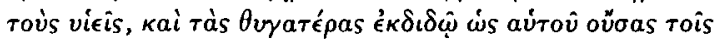
$a ́ \nu \delta \rho a ́ \sigma \iota)$ does constitute some additional evidence against the assumption that girls were introduced to phratries: his distinction is precisely in line with the difference in practice which I have already stressed (p. 4I, ff. p. 46).

31 Gomme (n. 4) 94. 
II. LAW

Before I come to the first I think I should draw attention to one crucial ambiguity in my title (and in the titles of most other essays which deal with this question). When we speak of the social position of women, and mean by that more than just the social milieu in which they move, we are being dangerously vague in the terms we use, for it will make a very great difference whether we are speaking of women as daughters, as sisters, or as wives, and whether as wives or mothers; and it may make an equal difference whether we are speaking of the women of the rich or of the poor. We shall have to bear this vagueness in mind as we proceed: for the moment I only draw attention to it.

I have already mentioned the striking lack of interest in discussions of the social position of women in their juridical status. Gomme, as we would expect, defends this omission, but by arguing, it seems, that there is no connection between legal and social status. I do not imagine that most women today, let alone supporters of women's lib or the suffragettes of two generations ago, would agree. We cannot simply say that status before the law is no part of what we must attend to if we are to define the place of women within the structure of a given society, even though from a male point of view (since laws in antiquity, as largely today, were made by men) this might be a comfortable way out. The law is surely beyond dispute one of those sets of social institutions by which society seeks to define its inner structure. We cannot simply ignore it. In the case of Athens during the fifth and fourth centuries the factual position is well enough known and can be treated fairly briefly: ${ }^{32}$ I shall be more concerned with the significance of the facts and their relation to other facts which help to define the position of women.

The juridical status of women in Athens is beautifully indicated by the single entry under 'women' in the index to Harrison's Law of Athens i: it reads simply 'women, disabilities'. A woman, whatever her status as daughter, sister, wife or mother, and whatever her age or social class, is in law a perpetual minor: that is, like a male minor, but throughout her life she was in the legal control of a male kyrios who represented her in law. If unmarried she was in the kyrieia of her father, her brother(s) by the same father, or her paternal grandfather. Upon marriage a kind of divided kyrieia arose: the evidence seems to suggest that a father could dissolve his daughter's marriage, even against her wishes, ${ }^{33}$ whereas in other respects the husband acts as kyrios. On her husband's death she either passes to the kyrieia of her son(s) (if any) or reverts to that of her father if still alive: if her sons are minors she falls under the kyrieia of their kyrios. If she is pregnant on her husband's death she may (and perhaps must) remain in the kyrieia of whatever male affine will become her future child's guardian, ${ }^{34}$ that is to say, in the oikos of her deceased husband. In relation to marriage the most instructive case of female disability at law is, of course, the situation of the epikleros. ${ }^{35}$ If a man dies leaving only a daughter or daughters, none of whom is married to

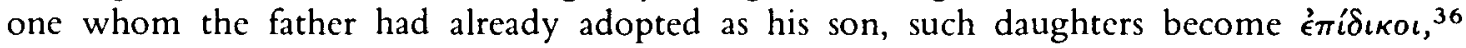
'assignable', and are 'assigned' by the archon eponymos to the nearest male kinsman in a fixed order of precedence. ${ }^{37}$ Even if already married her existing marriage could be (and sometimes was) dissolved in order to allow her to be assigned in this way. ${ }^{38}$ The order of precedence proceeds through the agnatic line, starting with the dead father's brothers, and failing any in this line, through the cognatic: the set of those to whom an epikleros could be assigned is the anchisteia and this set exhausts the class, not only of those who may marry an epikleros, but also of those who

\footnotetext{
32 The best full discussion is that of Harrison, Law of Athens i (n. 27) though the structure of the book means that discussion of the juridical status of women is scattered through the volume. Sec also the lucid treatment by D. M. MacDowell, Law in Classical Athens (London 1978) 84-108 and the uscful brief account in Gomme and Sandbach, Menander: a commentary (Oxford 1973) $28 \mathrm{ff}$.

${ }^{33}$ Dem. xli 4 ; Men. Epirr. 655 ff., 714 ff. (all refs to Menander follow the numbering of Sandbach's Oxford text); P. Didot I; Harrison i $30 \mathrm{ff}$. and 3 i n. 1 . In the first case from Menander, the ground on which the marriage is to be dissolved is the husband's (supposed) dissipation of the dowry.

${ }^{34}$ Harrison i 39 and n. 2, 44, I I I.
}

${ }^{35}$ On epikleroi, see Harrison i $9 \mathrm{ff}$., I $32 \mathrm{ff}$; Gernet, $R E C$ xxxiv (1921) 337-79. The new fragments of Menander's Aspis provide fresh evidence, especially as to attitudes: see esp. $114-46,168-87,254-73$.

${ }^{36}$ It is to be noted that the word émí $\delta_{\iota \kappa}$ is used indifferently of the epikleros and of the property that 'goes with' her, or perhaps, more revealingly, 'with' which she 'goes': Isae. vii 3 ; ii 2; vi 4 ; D.H. Isaeus I 5 ; Dem. xliv 46 ; Harrison i 95, i $56 \mathrm{nn} .2$ and 3.

${ }^{37}$ The full anchisteia is set out in order in Harrison $i$ $144-6$.

${ }^{38}$ Isac. iii 64; Harrison i 11 f., $309 \mathrm{ff}$. Or a man might divorce his wife in order to lay claim to an epikleros: [Dem.] lvii 4 I-3. 
may inherit and those who may avenge in law the death of a murdered man: this coincidence of rules of marriage, rules of succession and rules of vengeance is certainly significant. ${ }^{39}$

The position of the epikleros is an extreme instance of the general rule that a woman has in law no standing in any question relating to her marriage, ${ }^{40}$ just as she has no legal right to own or dispose of property ${ }^{41}$ (I am using 'just as' here in its strongest sense: the two disabilities are parallel and connected): in other cases it is her kyrios who, in law, determines whom a woman shall marry, and included in this right of the kyrios is a husband's right to dispose of his widow-to-be in prospect of his death. ${ }^{42}$ The connection with property is maintained in the rules governing dowries: any dowry that went with the woman in marriage is controlled by her husband qua kyrios but cannot be disposed of by him; on the husband's prior death or on dissolution of the marriage the dowry passes with her to her new kyrios; on the death of the wife without children born to her, the dowry reverts to her original kyrios. The maintenance of these rules, like those which govern the care and protection of wives, epikleroi and wards, are the concern of society in its formal, legal aspect and were probably the responsibility of the archon-again just as the oversight of 'empty oikoi'. ${ }^{43}$ In all this what is most striking is the strict parallelism between the formal rules controlling the treatment of women and those that govern the transmission and inheritance of property and of the right or obligation to avenge. Two further points will serve to bring this parallelism into sharper focus. The first act of the archon on entering office was to

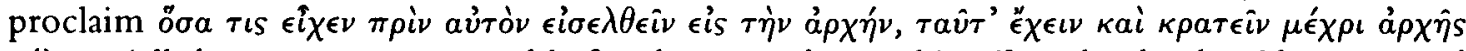
$\tau \in$ tevo: 'all that any man possessed before he entered upon his office, that he should possess and control until the end of that office'. It is hard not to see the archon's responsibility for preventing the ill treatment of women who are potential transmitters of property as stemming from this primary duty of protecting the rights of property. And the association of women and property is beautifully realised in the dual use of the word '́ $\gamma \gamma \dot{v} \eta$ : Harrison rightly draws attention to $\mathrm{H}$. J.

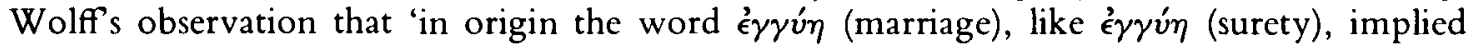
transference with a reserved right to the transferor'. ${ }^{44}$ The common element of a retained right in what is transferred derives, in the case of marriage, as Wolff points out, from the fact that the role of the woman in the transmission of property is a dual one: she may be required to produce the son necessary to ensure continuity of the oikos in the descent line of her father as well as (or instead of) in that of husband: ${ }^{45}$ hence, of course, the institution of the epikleros.

It is thus in their role as transmitters of property that the community displays concern for and extends protection to its women, and expresses such concern and protection within its formal, legal rules and institutions. The way in which it does so defines the woman as incapable of a self-determined act, as almost in law an un-person, outside the limits of those who constitute

${ }^{39}$ As is the fact that the maintenance of women, like the assignment of epikleroi, is a concern of society in its formal, legal aspect: such concerns are covered by the $\delta i \kappa \eta$

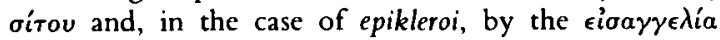
$\kappa \alpha \kappa \omega ́ \sigma \epsilon \omega s$. In the latter case, proceedings could be insti-

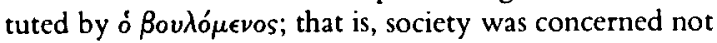
only to uphold the right of kinsmen to protect their women, but in this instance widens the boundaries so as to uphold a similar right on the part of an $\gamma$ of its members: see Harrison i i $7 \mathrm{ff}$., and esp. Isae. iii 46-7. Conversely, the marriage ritual itself is not an institution in which society is concerned but a matter only for the kin and the phratry: see E. J. Bickermann, Bull. dell' Inst. di Dir. Rom. lxxviii (1975) 1-28. And bastardy was (in all probability) no bar to citzenship: see Harrison i 63-5; MacDowell, CQ xxvi (1976) 88-9 I.

40 The case of Alcibiades' wife, Hipparete, produces an apparent exception: according to Plutarch's version of the story (Alc. 8. 4-6), Hipparete, wishing for a divorce from her husband, whom she had already left, could not be represented by others but had to present herself in person

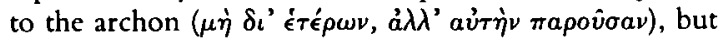
other instances of the procedure (Dem. $x x x$ I $5-17,26,3 \mathrm{I}$; Isae. iii 78 ) show a male kinsman acting for the woman. It is likely that here too Hipparete's divorce is formally registered on her behalf by her brother, but that the law required her to be present in the archon's office: see Harrison i 40-3; MacDowell (n. 32) 88.

41 See de S:e Croix, CR xx (1970) 273 ff. David Schaps, $C Q \times \times v$ (1975) $53-7$, has pointed out that inheritance in Athenian law is not strictly agnatic, since the sons of daughter or sister may inherit and not merely those of a son or brother: the rule is merely that males precede females in the same degree of kinship. But if the test of ownership is the right to dispose of property, then females do not 'own' what they 'inherit' and are merely transmitters of property to their male descendants.

42 The best attested cases are, of course, those of Demosthenes' mother and sister (Dem. xxviii i $5 \mathrm{f}$.), and of Pasion's wife, married to Phormion (Dem. xxxvi 8) by will.

${ }^{43}$ Arist. Ath. Pol. s6. 6; [Dem.] xliii 75; Isae. vii 30 ; Harrison i 47 n. 2, 57 n. 2, 90 ff., 101 ff.

${ }^{44}$ Harrison i $32 \mathrm{n}$. I, citing Wolff, Traditio ii (1944) sI ff. = Beitr. zur Rechtsgesch. Altgriechenlands u. des hell.-röm. Aegypten, $170 \mathrm{ff}$.

45 Wolff (n. 44) $50=168$. 
society's responsible and representative agents; and yet, at the same time, as precious and essential to the maintenance of a continuing social order and in particular to the continuity of property. ${ }^{46}$

This contradictoriness of status becomes even more marked in the anomalous situation which we find when we try to define formally the sense in which a woman is a member of the community. In one sense, as we have already noticed, she clearly stands outside: she is not registered on the deme register and she is not a member of a phratry. ${ }^{47}$ It is significant that the pattern of naming and referring to women in public contexts reflects this: here we have a clear instance of 'muting' in Ardener's sense. On Attic tombstones of women, even of the Hellenistic period, when a demotic (indicating membership of the community) occurs it agrees invariably with the name of the dead woman's father or husband, not with her own name: this contrasts with the case of non-Athenians, where the ethnic normally agrees with the name of the woman. ${ }^{48}$ The situation in legal contexts is even more striking. In the private speeches of Demosthenes twenty-seven women are actually named, in eight speeches: fourteen of these occur in one speech, Apollodorus' speech against Neaira, and significantly ten of these are alleged to be hetairai: the remaining four are slaves. There are for comparison five hundred and nine male names spread over thirty-three speeches. Demosthenes' own mother and sister, though he refers to them repeatedly in the five speeches devoted to the tangled issues of his inheritance, are never named. ${ }^{49}$ Neither is the unfaithful wife at the centre of Lysias' first speech, though the story of the marriage is told in considerable detail. This is not accidental: David Schaps has recently shown how systematic is the avoidance of women's names throughout the speeches of the Attic orators. ${ }^{50}$ The only exceptions are women of low status or none (prostitutes, slaves); women connected with one's opponent (a clear extension of the first category); and the dead. Thus the names of women who have a respected place in the community are suppressed and they are referred to by complex periphrases which stress their status-dependence upon male kinsmen. ${ }^{51}$ Respect requires that they be treated, almost, as part of the property of father or husband. We may compare these facts both with our own system of surname changing by women upon marriage and with modern Greek usage, whereby a woman's surname is that of her father, then of her husband, in the possessive: 'so and so's Miss or Mrs'. ${ }^{52}$ Maniote custom is even more extreme: to address a married woman by the possessive use of her husband's Christian name, and never utter the woman's first name at all. ${ }^{53}$ Recently Caroline Humphrey has described and analysed a complementary system of naming behaviour among the nomads of Mongolia, where a woman is not allowed to utter the name (or any homophone of the name) of any of her senior male affines (her husband's older brothers, his father, his father's brothers, or grandfather): she explains this taboo persuasively as being grounded in the social necessity not to command the attention of any senior affine to 'someone whom [their own] agnatic ideology insists on suppressing'. 54

Thus in these contexts it is as though the woman has no personality and exists only as an extension of her male kyrios. On the other hand, after Pericles' citizenship law of $45 \mathrm{I} / 50$ and its

\footnotetext{
${ }^{46}$ See the comments of L. Gernet, Anthropologie de la Grèce antique (Paris 1968) 83 f., $354 \mathrm{ff}$., and especially his words: 'si les filles sont gardées, c'est qu'elles sont un bien précieux . . . l'epiclérat classique où la femme, minorisée, est pourtant l'object d'un respect formel'.

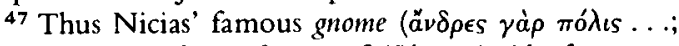
Thuc. vii 77. 7: $f$. Eur.fr. $828 \mathrm{~N}^{2}$ (Phrixos); Alc. fr. I 12.10 LP) means exactly what it says.

${ }^{48}$ See the examples collected and analysed by $A$. S. Henry, CQ xix (1969) 298-305. The demotic normally agrees with the name of the woman's кúpios where it is used in references in the orators also: [Dem.] lvii 68 .

${ }^{49}$ The possible explanation, that his mother was a 'Scythian' (Aeschin. ii 93; iii I 72; Din. i I s) and therefore unnamed, will hardly convince: see J. K. Davies, Athenian Propertied Families (Oxford I971) I 2 I $\mathrm{f}$. The same pattern can be seen in references to Onetor's sister, married to Aphobos, and to the woman that Aphobos later married,

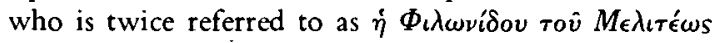
(Dem. xxvii $56 ; x \times i x ~ 48)$ : neither is named.

${ }^{50}$ CQ xxvii (1 977) 323-30.
}

51 The paradigm case perhaps is [Dem.] $\mathrm{xl}$ 60. Schaps (n. 41) 330 explains the tendency as involving the conferment of respect indirectly: "A "woman" was not somebody to respect; but somebody's mother-or sister, or wife, or daughter-that was another matter'.

52 See R. Hirschon in S. Ardener (ed.), Defining Females (London 1978) 74 and 87 n. 5; also Shirley Ardener's own remarks, 2 I-3. Juliet du Boulay Portrait of a Greek Mountain Village (Oxford 1974) I4 n. I, points out that at Ambeli, though the men celebrate their 'name-day', the women have no such celebrations.

${ }^{53}$ M.J. Lineton, Mina present and past: Depopulation in a village in Mani, Southern Greece (Ph.D. thesis U. Kent at Canterbury, 1971) 101. Compare the Sarakatsani, among whom a married woman is addressed always by a special 'andronymic' form of her husband's Christian name, never by her own: J. K. Campbell, Honour, Family and Patronage (Oxford 1964) 69-71.

54 'Women, Taboo and the Suppression of Attention' in S. Ardener, ed. (n. 52) 89-108: quotation from 107. 
re-enactment in $403 / 2$ the citizenship of a male Athenian and hence his legal personality depend upon his being the son of a mother who was, in Plutarch's formulation, 'Athenian'; 55 the word regularly used is $\dot{\alpha} \sigma \tau \eta^{\prime} .{ }^{56}$ But status as an $\dot{a} \sigma \tau \eta^{\prime}$ is not easy to define. It is noticcable that Aristotle offers no definition in the Politics. ${ }^{57}$ As we have seen, it is characteristically through her relationship to males or by her participation in deme or other rituals and by evidence of her marriage that a woman's status is upheld in courts of law: ${ }^{58}$ in other words, where it is not derived from kinship with males, a woman's status tends to be defined in terms of ritual functions. ${ }^{59}$

In terms of law we are left then with a situation which appears internally contradictory and with definitions that seem inherently circular: women stand 'outside' society, yet are essential to it (and in particular to its continued, ordered existence); their status derives from males but theirs, in turn, from the women who are their mothers.

\section{Custom}

In talking of law we have been talking about formal structures, the formal rules by which society attempts to regulate its own inner relationships and in so doing inevitably gives these relationships definition. When we speak of 'custom' we are speaking of something much less easy to define but which embraces roughly the informal patterns of behaviour and the norms and attitudes which are implicit in such behaviour. We shall be interested both in the actual patterns of behaviour that we can discern and also in the expected patterns, the set of roles in terms of which men and women express their sense both of themselves and of the other, and of the relationship between them which the ordered existence of society requires. That Athenians in particular had a highly articulated sense of such a set of roles is clear from such well-known instances as Meno's attempt to define arete in Plato's dialogue. ${ }^{60}$

Now in approaching the question of custom as it concerns the social position of women at Athens it is important, once again, to make ourselves a ware of and be on our guard against the dangers of rationalisation and a priori argument. Those who, like Gomme, have sought to deny that anything that might be termed 'seclusion' was characteristic of the customary treatment of women have evidently been largely motivated by their sense that if Athenian women were 'secluded' it must follow that they were regarded and treated by men with 'contempt'; that in some way, occupying the same space as men or moving in space with the same freedom is a necessary condition of equality of regard, or even of any degree of 'respect' felt and shown by men to women. Gomme and his followers seemed to feel that if it is accepted that there were physical boundaries separating men from women in Athenian society, then in the eyes of men women are disregarded and despised and no account taken of their feelings in decisions that we should see as involving both. But of course it does not follow and the evidence is enough, I think, to show that it was not so.

On the one hand evidence for the existence of separate spheres of activity and within the house for separate areas of customary life is so strong and widespread that only a very powerful

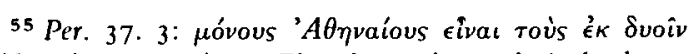
'A (almost certainly that actually used in the law) is $\mathfrak{\epsilon}^{\prime} \xi \dot{\alpha} \mu \phi \circ \hat{\nu} \nu$ áoroî.

56 Not $\pi$ oגirıs: the latter exists (see n. 17 above), but it is important to see what it denotes. A woman is a moגitıs only as the daughter, sister, wife or other kin of a male

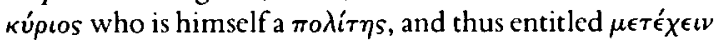

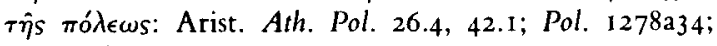
[Dem.] lvii s I; Isae. iii 37.

57 The word occurs only twice: once in a statement of the most restricted form of citizenship qualification in a

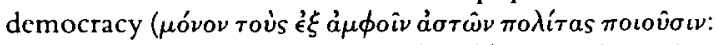
I $278 \mathrm{a} 34$ ); the other time opposed to $\xi$ '́vo of different types of homicide court; 130ob3 I $f$. One particularly interesting passage ( $1260 b_{13}$ f.) opposes women, as $\tilde{\eta} \mu \iota v \nu \mu$ épos $\tau \hat{\omega} \nu \dot{\epsilon}^{\lambda} \lambda \epsilon \theta \dot{\epsilon} \rho \omega \nu$, to male children

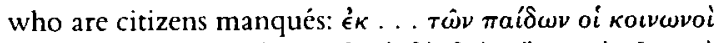

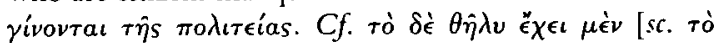

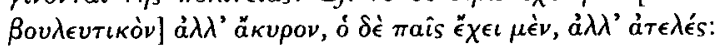

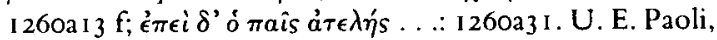
Studi di diritto attico (Florence 1930) 258-64 is still the best discussion of the two terms.

58 To the passages cited in $n .18$ above, add [Dem.] lvii $4 \mathrm{I}-3$ (evidence of marriage proving the status of an $\left.\dot{\alpha} \sigma \tau \eta^{\prime}\right)$.

${ }^{59}$ It is relevant here that though a woman could not give evidence in a court of law, she could swear an oath, and that oath could be produced in hear-say evidence, otherwise excluded: Harrison i 79 ; $\mathrm{M}$. Shaw, $C P h \mathrm{lxx}$ (I975) $257 \mathrm{n} .11$.

${ }^{60} \mathrm{Pl}$. Meno 7 I - $72 \mathrm{a}$ : of. Arist. Pol. $1259 \mathrm{~b} 28$ (the whole passage is of great importance and particularly revealing); Poet. I454a16 ff. 
rationalising need could account for its being denied or ignored. I have already mentioned cases where this customary separation impinges on the social order of Greek tragedy; the orators provide us with more than enough to satisfy the most sceptical that such separation of male and female areas of life was normal. The evidence of the orators on this point has been well used by Lacey, ${ }^{61}$ and I have space only for two examples. One of the climaxes of the sad and tangled story of the ship's gear that is the subject of [Dem.] xlvii brings the speaker to the house of the devious Theophemos: ${ }^{62}$ his need is now becoming desperate; the fleet is about to sail and the Council has passed a resolution requiring all trierarchs to regain possession of missing gear from their predecessors in office 'by any means they could'. Theophemos is out but the slave girl who answers the door is sent to fetch him. The trierarch waits at the door and Theophemos returns, but he prevaricates and is insulting. The trierarch sends his slave to gather witnesses as to what happens next; he tries further argument with Theophemos and declares that if the gear is not forthcoming he will seize '́ $\nu^{\prime} \chi \chi v \rho \alpha$ (securities). This he does by grabbing the slave girl (they are still standing by the door). Theophemos resists and now the trierarch goes into the house to seek an alternative object to seize as security for the gear. At this point he pauses for a moment in his narrative to the jury and explains (a) that the door was open (he was not breaking in) and (b) that he had immediately with Theophemos punching him in the mouth and his dramatic return to the meeting of the Council. It is the brief aside that we should notice: even in this crisis a self-respecting Athenian is not going to run the risk of coming face to face with another man's wife in his own home. The trierarch's admirable restraint is clearly intended to contrast with the outrageous behaviour of Theophemos' brother and brother-in-law who later in the story, ${ }^{63}$ in a balancing episode, break into the speaker's country farmhouse and confront his wife and children and an old nurse eating in the courtyard: the remaining slave women of the household were in the 'tower', 'where they lived' and barred themselves in. ${ }^{64}$ Violence breaks out (the trierarch describes his house as 'in the process of being sacked') and the shouting attracts the attention, first of neighbours' slaves and then of a passing neighbour, Hagnophilos. None of these enters the house: the slaves stand on the roofs of their own farm buildings or go into a nearby lane, trying to attract the attention of passers-by, and Hagnophilos stands on another neighbour's land and witnesses the scene. Hagnophilos did not go in, the trierarch explains to the jury, because 'he did not think he was justified in the absence of the head of the family (kyrios) from the house'. Few passages, perhaps, bring out so clearly the sense of an inviolable boundary separating the free women of a household from unrelated males and of the outrage implicit in male entry upon the women of another kinship group. But several others, less dramatically, point to the same conclusion. ${ }^{65}$

The speaker of Lysias i, Euphiletos, is charged with murder: it is therefore vital for him to show that there was no premeditation, and he provides a highly circumstantial account of all that led up to the killing of his wife's lover. ${ }^{66} \mathrm{He}$ lays stress on the (apparent) normality of relations between himself and his wife: whether he is telling the truth or not is irrelevant to us. All we need bear in mind is that Euphiletos' domestic life is intended to sound normal. He describes the lay-out of his house, with its separate quarters for men and women, and how his wife, who was feeding their baby, frequently slept in the women's quarters so that she could feed and wash it in the night. The picture that emerges is, as it is intended to be, simple and convincing: a wife who leads a private, sheltered life, who goes out little (the affair with Eratosthenes begins, as so often in Menander, with a first sight of her at a public religious ritual, in this case a funeral); ${ }^{67}$ whose

61 W. K. Lacey, The Family in Classical Greece (London 1968) 158-62, 167-9 with the nn. on $304 \mathrm{ff}$.

${ }_{62}[\mathrm{Dem}$.$] xlvii 35-42$.

63 Ibid. 52-6I.

${ }^{64}$ For towers as part of a farm-building complex in Attica, see J. H. Young, Hesp. xxv (1956) 122-3 I, 133-43; J. E. Jones, A. J. Graham and L. H. Sackett, $B S A$ lxviii (1973) 436-8 and fig. I6; and for a general discussion, J. Pecirka in M. I. Finley (ed.), Problèmes de la terre en Grèce ancienne (Paris 1973) 1 23-8, 134-7, 143.

${ }^{65}$ See especially Lys. iii $6-7,23$; Dem. xxxvii 45 ; xxi $78-9$. The absence of women from the scenes of house searching described in Lys. xii 8-16 is striking: the proba- bility is that he was married and that his mother was living with him ([Dem.] lix 21-2; Dover, Lysias and the Corpus Lysiacum [Berkeley 1968] 36-8). It is also worth noting that on more than one occasion it is the evidence of slaves that is sought to support the assertion that a woman has been living in a house (Dem. xxx 27; Isae. vi $13-16$; viii 9-10, 14): in each case it is implied that the point is a difficult one to establish, except through the evidence of slaves.

${ }^{66}$ Lys. i 6-27.

${ }^{67}$ Lys. i 7 : $f f$. Men. Epitr. 45 I ff. 47 I ff. (Tauropolia); Sam. $38 \mathrm{ff}$. (Adonia), and, presumably, Phasma $93 \mathrm{ff}$. 
shopping is done by a slave woman; ${ }^{68}$ who, once her child is born, is no longer under her husband's surveillance, ${ }^{69}$ but who is not expected to be present when Euphiletos brings home a male friend for an evening meal. ${ }^{70}$ This last is of course a well-known feature of relationships within marriage in classical Athens: evidence of eating and drinking together with males who are not kinsmen is frequently presented in Athenian law courts as by itself establishing that a woman is a pallake or hetaira but not a wife. ${ }^{71}$

This overall picture is not one that we have any a priori right, or evidence on which, to challenge. It can be reinforced in two ways. The first is from the evidence of house plans and vase paintings, ${ }^{72}$ as well as the comparative evidence of other cultures. Greek houses seem almost always to have one external door only: there is no 'back door' at or through which women may come into contact with other outsiders than those who enter the house through the 'front door'. The men's quarters are commonly near to this street door or across the courtyard from the sole entrance. In two-storey houses it is a fair inference from the evidence of Lysias $i$ that the women's quarters were normally on the upper floor: hence, it seems likely, the association between the women's quarters and the $\mu v \chi$ ós, 'recesses', of the house. ${ }^{73} \mathrm{On}$ Attic vases women are characteristically seen indoors and in the company of other women. Outside the house they are shown fetching water and taking part in religious rituals, or in the doorway saying farewell to men leaving the house. ${ }^{74}$ In ancient Greece, as in modern, the woman's orientation is domestic: "of the house' as against 'of the road'. ${ }^{75}$ Moreover, the spatial distinction has its analogue in the temporal definition of a woman's role. It is of the essence of women's tasks that they be time-consuming; the provision of food, combing and spinning wool, weaving. The significance of this has recently been brought out by Hirschon in her study of female sexuality in a Peiraeus neighbourhood: just as spatial seclusion protects the woman from contact with males not of her own kin, so time-consuming tasks keep her out of mischief (the symbolism of Penelope's weaving is certainly relevant here, as is the night-milling slave woman of $\mathrm{Od} . \mathrm{xx}) .^{76}$

The description I have been offering is sometimes qualified by the caveat that it can only be true of those Athenians wealthy enough to own slaves and thus keep their women from the necessity of leaving the house to buy food or even to work. ${ }^{77} \mathrm{I}$ am not happy about this if it is taken to mean that the sense of an inviolable boundary marking the separateness of male and female 'territories' and areas of activity was a preoccupation only of the rich. Of course the women of the poor worked ${ }^{78}$ outside the house, but I would suggest that such activity may not have been seen as a normal part of the female role and that its exceptional nature may have been marked by some residual sense of a boundary still separating them and marking them off from the strange males with whom they must have come face to face. I have in mind two parallels from modern Greece. The first is from Ernestine Friedl's account of life in a Boeotian village: 'for the most part ... the world of the aghora [which in the case of Vasilika is merely a stretch of the one

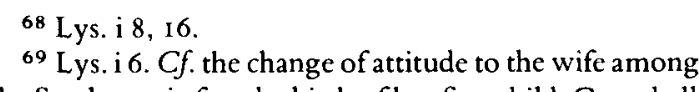
the Sarakatsani after the birth of her first child: Campbel] (n. 53) 69-71.

${ }^{70}$ Lys. i $22,39-40$. Contrast the presence of the pallake at the fatal meal of Philoneos and his friend (Antiphon i 16-20). Again the Sarakatsani provide a close parallel: Campbell (n. 53) is I.

71 For examples, see Isae. iii I3-14; [Dem.] lix 24, 33, 48. It is perhaps worth underlining the fact that Neaira, whose status is in dispute in [Dem.] lix, moves, when in Athens, in very good circles indeed: for Chabrias, see Davies (n. 49) $560 \mathrm{ff}$; for Phrynion, $143 \mathrm{f}$. There is no question of her being a demi-mondaine.

${ }^{72}$ For the points made in this paragraph, I owe much to work being done by Susan Walker and Ian Jenkins of the Dept. of Greek and Roman Antiquities at the British Museum, work as yet unpublished but which promises to throw considerable light on the customary norms which define women's roles in spatial terms. For an instructive and detailed analysis of the spatial definition of male/female roles in terms of the house plan in Kabyle society, see
Bourdieu's essay, 'La maison Kabyle ou le monde renversé' in Échanges et Communications (The Hague 1970) ii 739-58, rep. in Esquisse d'une théorie de la pratique (Geneva 1972) 45-69; in Eng., in Algeria 1960, $133-53$ and (shortened) in Mary Douglas (ed.), Rules and Meanings (Harmondsworth 1977) 98-1 10.

${ }^{73}$ Hom. Il. xxii 440 f; A. Cho. 35 ff., 446 ff., 877 ff.; Eur. Med. $395 \mathrm{ff}, \mathrm{Hel} .8 \mathrm{I} 9 \mathrm{ff}$, fr. $1063 \mathrm{~N}^{2} .3$.

${ }^{74}$ The door is at all periods the boundary at which women may stand, watching the scene outside and perhaps gossiping: Hom. Il. xviii 495 f.; Men. fr. $\$ 92$.

${ }_{75}$ Hirschon, in S. Ardener (n. 52) 80 f.; du Boulay (n. 52) I 30-5; more generally, Michelle Z. Rosaldo, in M. Z Rosaldo and L. Lamphere (edd.), Woman, Culture, and Society (Stanford 1974) 23-42.

${ }^{76}$ Hirschon (n. 52) 83 f.; S. Ardener (n. 52) 17 f.; Hom. Od. xx IOS-IO.

77 For example, de Ste Croix (n. 4I) 278.

78 For examples, [Dem.] lvii $30 \mathrm{ff}$.; Ar. Wasps $496 \mathrm{ff}$., 1388 ff.; Frogs 857 f.; Anacr. PMG 388.4-5; and of course such figures of comic fantasy as Euripides' mother. 
village street defined by social custom], and, indeed, the public world of the village, is a male world penetrated sporadically by children of both sexes. . . . men do the marketing from the pedlars of fresh foods and buy whatever items are needed from the village stores. Little girls up to the age of twelve or fourteen, alone or with their brothers, may be sent to the aghora on errands, but older girls and women will venture into the area only to pass through it on their way to church or to the fields. I have seen a young mother from the eastern end of the village, when she heard the calls of a tomato vendor, walk to the edge of the aghora area. She stood some two hundred feet from the tomato wagon, shouted to the pedlar to ask what his prices were and then waited in the same spot until she could send a passing child to buy her tomatoes for her. ${ }^{79}$ The other is from an experience of my own. Driving through Crete I passed a remote threshing floor on which a man and two women were winnowing wheat. I got out of the car to take a photograph and as I came nearer the two women retreated rapidly and, while I remained, stayed crouching more than half out of sight in the heavy shade of a tree: the man continued with his work while I took my photographs. Physically, the women were in the public world, but in a privileged and bounded position within it: the approach of a male stranger activated the sense of separateness implicit in their role and forced physical expression of it. I think we have to bear in mind the possibility of such submerged lines of demarcation in Classical Athens also.

However, as I have suggested, it does not follow from this state of things that 'contempt' is the appropriate term to describe male attitudes to, or behaviour towards, women. The evidence indeed contradicts any such assumption. But in examining it we have to make three preliminary distinctions: the first between private and public worlds, between 'inside' and 'outside' and the behaviour appropriate to each; the second between relationships which associate women with male kinsmen and the absence of any such relationships with unrelated males; and the third between relationships with men in general and those with other women, in particular the network of gossip relationships with neighbouring women. There is a nice example of the last in the water-rights case against Kallikles, Dem. lv. The speaker is arguing that any flood damage caused on Kallikles' estate by his father's having built a wall along the road separating the two estates, was minimal, and he produces the hearsay evidence of a conversation between his mother and Kallikles' mother which took place during a visit made by the former (by implication a normal occurrence) ${ }^{80}$ The impression left by this speech is of two parallel networks of relationship between unrelated neighbours, one involving the men, the other the women. ${ }^{81}$ What we do not find is any sort of relationship pattern between neighbours of opposite sex, and that is what we should expect from the evidence already produced.

On the other hand, relationships between women and their male kinsmen can be very close, can display a very high degree of warmth, tenderness and concern; ${ }^{82}$ of mutual understanding and tolerance; and of male acceptance, not only of the right of women to be consulted, but also of the initiative of women in the affairs of the family. On the other hand, of course, we can find in the evidence examples of an equally striking absence of these qualities. ${ }^{83}$ These facts will surprise only those who have accepted Gomme's tacit assumption and infer from the evidence for 'seclusion' that such human feelings cannot have existed between men and women or, conversely (like Gomme himself) feel certain of the latter, and find themselves therefore impelled to deny the former.

${ }^{79}$ E. Friedl, Vasilika, a village in modern Greece (New York 1962) 12. Compare Hirschon's experience of how women react to conflict between the pressures of everyday life and traditions of ritual seclusion after child-birth, (n. 52) 81: 'Nowadays, when women cannot always rely on the presence of close family to help them with their errands, mothers of new babies may have to go out to the neighbourhood shop, but they will always avoid entering it and will stand outside on the doorstep and ask for their purchases to be brought to them.'

${ }^{80}$ Dem. lv 23-4, 27: it is again noteworthy that the two mothers are not named. Theoc. xv shows the same pattern of gossip relationships in third-century Alexandria; on women and gossip in modern Greece, see du Boulay (n. 52) 204-13, and on gossip, scandal and slander

generally, Campbell (n. 53) 192, $210,291_{-2}, 312-15$.

81 For neighbourly relationships between the men, see Dem. op. cit. $3^{-5}$.

82 It is worth noting in passing that even the infamous Neaira, as Apollodorus mentions without remark, left

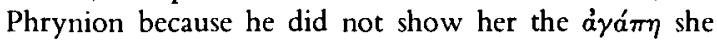

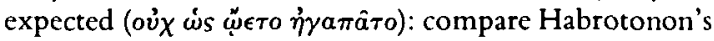
misery at her treatment by Charisios in Men. Epitr. $430 \mathrm{ff}$.

83 This variety of behaviour is reflected in the dramatic world of Menander: contrast the two scenes of giving in marriage in Dysk. (69 I ff., $847 \mathrm{ff}$ ), in which a sister and a daughter are given in marriage in their absence and the women are only called out at the end as witnesses, with the argument between Pamphile and her father in Epitr. $7 \mathrm{I} 4 \mathrm{ff}$. (above p. 43 and n. 33), and the Didot papyrus. 
Let me look at some examples. Lacey has made good use of the scene described in Lysias xxxii in which Diodotos' widow makes a long and impassioned speech to her male kinsmen on the subject of her husband's will and her father's infamous behaviour over what was left in trust for her and for her children. ${ }^{84}$ It is a striking instance of free and equal interchange between men and women on the domestic interests of the family. A narrative in Isaeus is less dramatic but equally revealing. In Isae, ii the speaker describes how he and his brother are approached by their brother-in-law, Menekles, whose marriage with their sister has been childless. The reason, in Menekles' view, is his own age: it would be wrong, he suggests, for him to take advantage of his wife's 'goodness' and for her to grow old with him in childlessness. He asks the speaker and his brother to give their sister in marriage to another, with his consent. The speaker then describes how he and his brother urged Menekles to persuade his wife, their sister, to accept this: 'I would do, I said, whatever she agreed to'. The sister at first resists, then with reluctance agrees. ${ }^{85}$ Here, apart from the legal framework within which the conversation takes place, we do find certainly a familiar sense of human warmth in relations between men and women. Equally familiar, however different the circumstances, is the tone of voice in which Euphiletos and his wife talk to one another on that night when Euphiletos came home unexpectedly from his farm in the country. ${ }^{86}$ His wife's lover is in the house and the old slave makes the baby cry to give its mother an excuse to go downstairs. At first she acts reluctance and puts on a performance of pleasure at her husband's return after being away some time: Euphiletos begins to lose his temper and tells her to go down. 'Oh yes', she says, 'I know why: you want a chance to get your hands on the little slave girl. You have done it before when you were drunk'. Euphiletos laughs and his wife goes out, shuts the door behind her and pushes the bar across-it was meant to look like a joke and it worked. Here are relations between a 'secluded' woman and her husband, warm, intimate, familiar relations, and if there are others which display neglect and bitterness and misery ${ }^{87}$ that, too, is something we can find familiar. Not all husbands, certainly, could have replied as Kritoboulos to Socrates, that there were few, if any, to whom he talked less than to his wife. ${ }^{88}$ Indeed, even on the subject of the public life of a husband or brother or father, Apollodorus presents the women of the family as taking a lively, and at times an embarrassing interest: when you go home, he tells the jury in the Neaira case, you will have to explain and defend what you have done here in court, and he then describes a vigorous cross-examination followed by forthright comment. ${ }^{89}$ Again, not all men would have brushed aside such questions with the effortless superiority of Lysistrata's husband. ${ }^{90}$

But these examples, to repeat, are examples of relations between men and women who are

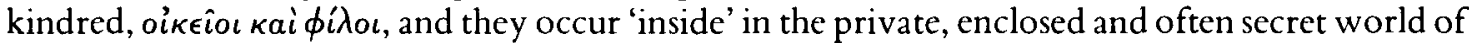
the Greek household. The world 'outside', the public world, is the world of men. In that world it is true that silence is the only ornament a woman has ${ }^{91}$ - with one striking exception. In the sacred and ritual activities of the community the active presence of women in the public world is not merely tolerated but required. As priestesses in many of the major cults of the polis (priestesses of gods as well as of goddesses), ${ }^{92}$ as kanephoro $i$ and hydrophoroi in the great religious processions, as the arrhephoroi of Athena Polias, the 'bears' of Artemis Brauronia, as raisers of the ritual scream, the $\delta \lambda o \lambda v \gamma \eta^{\prime}$, at the blood sacrifice, in mourning and at funerals, in the rituals of marriage, the

${ }^{84}$ Lys. xxxii I 1-18: she is literate and makes use of documents that her sons have found; once again Diodotos' widow remains unnamed throughout the speech. Other passages which show men and women discussing openly the finances of the family include Dem. xxxvi I 4; xli 8-21.

85 Isae. ii $7-9$. The role of the wife's brothers in this episode is instructive: J. van Baal has called attention to the protection afforded the wife in relations with her husband and affines by her brothers, and has pointed out that this derives from the status of women as 'objects' transferred by and between men: 'The part of women in the marriage trade: objects or behaving as objects?', $B i j-$ dragen tot de Taal-, Land-en Volkenkunde cxxvi (1970) 289-308=Reciprocity and the Position of Women (Assen/Amsterdam 1975) 70-96.
${ }^{86}$ Lys. i $11^{-1}-14$

${ }^{87}$ E.g. Aeschin. i 95-9; Andoc. i $124-7$.

88 Xen. Oec. 3. I I. As Lacey (n. 61) 163 rightly points out, in the context the admission is meant to be paradoxical-and humiliating to Kritoboulos.

89 [Dem.] lix I 10-I I.

90 Ar. LYs. 507 ff.

91 Soph. Ajax 293, quoted by Arist., Pol. 1260 azo. Strikingly similar variations between 'public' and 'private' behaviour occur among the Sarakatsani: sce Campbell (n. 53) is I-2, 191 .

92 Women act as priestesses in more than forty major cults: see H. McClees, $A$ study of women in Attic inscriptions (Diss. Columbia, N.Y. I920) $5 \mathrm{ff}$. The cults include those of Athena Polias, the Eleusinian Demeter, Apollo Delphinios, Dionysus 'in the Marshes'. 
participation of women is indispensable to the sacral continuity, the ordering of society. The magnificent Panathenaic procession of the Parthenon frieze displays the ritual splendour and solemnity of the woman's role. And alongside the great civic rituals in which women stand with men as equal participants are those other rituals, just as much part of the sacred action of the community, which are either the exclusive domain of women or in which women play the leading role-rituals such as the Arrhephoria, the Skira, the Thesmophoria, the Lenaia, the Adonia. In these too the community expresses its sense of the necessary participation of women in its continuing life. Walter Burkert has recently shown that the eight-month long ritual tasks of the two young girls called arrhephoroi, chosen by the archon basileus from the great families of Athens, constitute a rite of initiation and incorporation into the community; and how the sacred objects round which the ritual revolves - the peplos of Athena Polias and the snake or phallos, the áp $\rho \tau \alpha$ ('secret [unspoken] things') contained in the covered basket that the girls carried in their night descent to the cave and well under the north cliff of the Akropolis-celebrate and symbolise the dual function of women in the community: spinning and weaving, the making of clothes, the

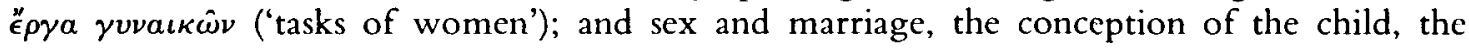
continued existence of the community itself. ${ }^{93}$

The participation of women in the cults of the community raises problems of interpretation. It cannot be wholly explained by adopting I. M. Lewis' recent suggestion, that these are 'peripheral' cults and that the role of women in them is to be understood as part of a strategy which can be widely illustrated from traditional societies, whereby women and others of low status, excluded from participation in the social and political life of the community, have found a mechanism to establish indirect claims to status and attention through possession and ecstasy, in a way which "ventilates aggression and frustration largely within an uneasy acceptance of the established order of things'. ${ }^{94}$ Such an explanation seems helpful with rituals such as the Adonia, or with the cult of Dionysus at the Lenaia. It seems less helpful when applied to the ritual of the sacred marriage at the Anthesteria, between Dionysus and the wife of the archon Basileus, or the cult of Demeter at the Thesmophoria. And it is surely quite untenable as an explanation of the participation of women in the cult of Athena Polias, from her priestess downwards. The cult of Athena, as expressed in rituals such as the Panathenaia, is not 'peripheral', but 'central', in Lewis' terminology: that is, its function is to reinforce official, 'male' morality and the dominant structures of society, and the role of women in it must seem anomalous. ${ }^{95}$

Moreover, in the ritual participation of women in community religion there are once again counter-indications to be noted, signs of that ambivalence and contradiction we have already seen in the judicial status of women. In the rituals of the Skira ${ }^{96}$ and Thesmophoria is enacted not the ordered continuity of society, but precisely its opposite, inversion and disruption: the women gather outside the house and apart, sexual relations are ritually in suspense, the norms of society disrupted. ${ }^{97}$ And at the Adonia the other pole of the ambivalence surrounding the role of women in ritual appears: sexual promiscuity and sterility. ${ }^{98}$

But with the intricate, half-hidden significations of ritual we have come close to my third aspect, myth. ${ }^{99}$

93 W. F. M. Burkert, Hermes xciv (1966) 1-25; Homo Necans (Berlin 1972) 169-73; Gr. Religion der archaischen u. klass. Epoche (Stuttgart 1977) 348 f., 353 f., 395.

94 Ecstatic Religion (Harmondsworth 1978) esp. 72-1 17 : quotation from 12 1; ref. to the cult of Dionysus 101.

${ }^{95}$ It is in keeping with this male ideology that Euripides derives the traditions whereby the priestess of Athena Polias is always drawn from the Eteoboutadae from the 'heroic' sacrifice by Erechtheus of his daughter's life to save Athens from the threat of invading foreigners: the first priestess was Praxithea, the wife of Erechtheus, who had joined him in sacrificing her daughter, declaring $\phi_{i} \lambda \hat{\omega}$

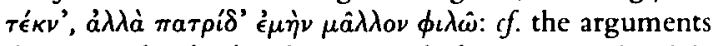
she uses to her husband (Eur. Erech. fr. so. 14-27 Austin), and for the actiology of the priestesshood of Athena Polias, ibid. fr. 65. 95-7. The role of the wife of the archon basileus at the Anthesteria is clearly presented by Apollo- dorus as being that of maintaining the sacred traditions of the (male dominated) community and its ideology: [Dem.] lix $72 \mathrm{ff}$., esp. 74-7. On religion and the reinforcement of status relationships, see the perceptive remarks of Burkert, Gr. Religion $387 \mathrm{f}$.

96 For the Skira, see esp. Burkert, Homo Necans, $161-8$; Gr. Religion, $349 \mathrm{f}$.

${ }_{97}$ Burkert, CQ xx (1970) 10-12; Homo Necans, 163-5; Gr. Religion, 172, 365-70; M. Detienne, Les jardins d'Adonis (Paris 1972) is 1 ff.; $215 \mathrm{ff}$; and now esp. Detienne in Vernant-Detienne, edd., La cuisine du sacrifice en pays grec (Paris 1979) I 83-214.

98 Detienne, Jardins d'Adonis $125 \mathrm{ff}, 187 \mathrm{ff}$.

${ }^{99} \mathrm{Cf}$. Burkert, $C Q \times \mathrm{xx}(\mathrm{1} 970) \mathrm{I}$, on the ritual of the Thesmophoria: 'in mythological fantasy, the separation of the sexes was escalated into outright war'. 


\section{MYTh}

With myth, we face major and intractable problems, both of definition and of method: no one who is familiar with Prof. Kirk's book and its reception, can be in any doubt of that. ${ }^{100}$ I propose to be cavalier about both. For definition I shall offer nothing more than what might charitably be called ostensive, and I think that no great harm will be done. Whether we define myth in terms of 'charter', 'archetype', 'fantasy' or whatever else, we are dealing with something recognisably different from what we have so far considered and which, however dreamlike, can serve as a vehicle for the mapping and understanding of experience in terms which are not available to a society in its more explicit rules and customary norms: myth can, and does, supplement these things, and may draw our attention to what is not otherwise visible to us, nor even, in all probability, consciously grasped by the tellers and hearers of it. As to method, I agree with many of the misgivings recently expressed by Brian Vickers, ${ }^{101}$ and faced with some of the more schematic binary interpretations of the structuralist school feel drawn irresistibly towards Mary Douglas' splendid remark: 'On this subject the stolid English suspicion of cleverness begins to crystallise'. ${ }^{102}$ I shall be eclectic, perhaps impressionistic, and hope that the results may justify me.

Let me begin with what will at first appear a random set of data. We have already noticed an example of the symbolic force of spinning and weaving in defining the social role of women in ritual. ${ }^{103}$ So too in myth. ${ }^{104}$ Louis Gernet has drawn attention to the interesting fact that in the mythical theme of the 'don fatal', it is commonly a garment of death that is the woman's gift: we have only to remember Eriphyle, Deianeira, Medea. ${ }^{105}$ The contribution to society has become the source of its destruction. Encounters between men and women in Greek myth regularly associate women with the wild and the sacred, with what is outside the limits of ordered civilisation, and with the forces of life, with mountains and forests, with rivers, springs and fountains. The correlation with fountains has its counterpart in modern Greek culture ${ }^{106}$ and has been well documented by Nicholas Richardson in his commentary on the Homeric hymn to Demeter. ${ }^{107}$ To his primary examples we can add, as well as Odysseus and Nausikaa, Odysseus' men and the Laistrygonian princess at the fountain Artakie (Od. x I03 ff.), Teiresias and Athena; and for the wilds, Aktaion and Artemis, Anchises and Aphrodite, Paris and the three goddesses, ${ }^{108}$ Paris and Oinone, ${ }^{109}$ Daphnis and the nymph, Hesiod and the Muses. In most of these, the encounter ends in the destruction of the man. On the other hand, there is an alterative pattern which stresses the secluded privacy of the woman (a young girl) and in which the encounter leads to her destruction: Kore and Hades, Kreousa and Apollo, Europa and Zeus, Helen and Hermes (Eur. Hel. 24I ff.), Stratonike and Apollo (Hes. fr. 26.18 ff.), Oreithyia and Boreas (Choer. fr. 5 Kinkel). ${ }^{110}$ The motifs of this second pattern of encounter revolve around the gathering of flowers, or the washing of clothes, and the peace and domesticity of the world of women, invaded by men. The ambiguities of the encounter are richly presented in the Kirke episode of the Odyssey ( $x$ I $35 \mathrm{ff}$.). In this, the association of normal and abnormal in sexual relations, of sex, witchcraft and the fear of castration, is reinforced by a parallel ambiguity in the physical and social setting of the scene: the wild, forested island inhabited by stags but with the civilised, domestic column of

\footnotetext{
${ }^{100} \mathrm{G}$. S. Kirk, Myth: its meaning and function in ancient and other cultures (Berkeley 1970) with the review in TLS lxix (1970) 889-9I; B. Vickers, Towards Greek Tragedy (London 1973) I66 ff., 617 ff. C. Calame, Quad. Urb. xiv (1972) I I 7-35; J. Perodotto, Classical Mythology: an annotated bibliographical survey (A.P.A.: Urbana Ill. 1973) 57-8. For a somewhat different version of his views, see also Kirk, JHS xcii (1972) 74-85.

101 Op. cit. (n. I00) $186 \mathrm{ff}$.

102 'The Meaning of Myth', in E. Leach, ed., The Structural Study of Myth and Totemism (London 1967) 60: the essay, indeed the volume as a whole, is a perceptive and sympathetic critique of structuralist method.

103 See above p. 51 .

104 The theme is prominent in the Odyssey: as well as Penelope's weaving, notice the first encounter with
} 
smoke rising from it; the stone-built palace in the forest clearing; the domesticated guard animals who are lions and wolves; the singing of the witch as she weaves at the loom. Nothing, we know, is as it should be, and yet everything is familiar. Even the civilised norms of the proper reception of the stranger-guest are (on the surface) minutely observed, ${ }^{11}$ but what results is the horror of dream-work, and Odysseus stands, sword in hand, as Kirke invites him to go to bed with her.

For the moment without comment, I will add some observations on the language of metaphor (male metaphor, we should remind ourselves) as it relates to women, sex and marriage. The formula required by custom if not by law, for giving in marriage is several times attested in

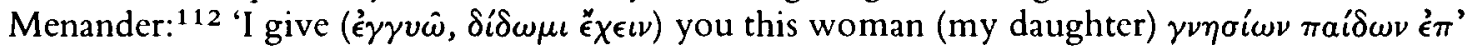
áó $\omega^{\prime}$ ', 'for the ploughing of legitimate children'. This traditional formula is part of a network of imagery and metaphor which associates women and their role in sex and marriage with animals, especially the taming, yoking and breaking in of animals, and with agriculture. Marriage is a

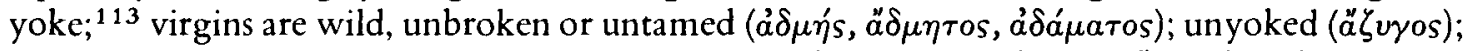

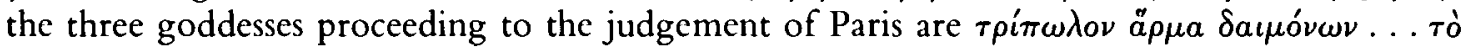
$\kappa a \lambda \lambda_{\imath} \zeta_{v \gamma \hat{\epsilon} \epsilon}$, 'a three-horse team of gods ... beauty harnessed'. ${ }^{114}$ Girls are young, unbroken horses ( $\pi \hat{\omega} \lambda a \iota)$; women are bitches (and here the overtones are of sexuality, not maliciousness). In the horrified kommos which crowns Oedipus Tyrannus, in Oedipus' words cited in the messenger speech, and already in the final stasimon, the imagery of plough-land and seed and furrow comes to dominate the coda of the play. ${ }^{115}$ Nor are these just the images of the extremity of horror: Deianeira speaks of Heracles' marriage with her in the prologue of Trachiniae as of a peasant visiting a distant field to sow and reap. ${ }^{116}$

Let me complete this job-lot of examples by two stories from Herodotus (with a little help from Plato): Herodotus will have thought them history, but I see no reason not to call them myth. The story of Gyges ${ }^{117}$ tells how an inferior member of the king's oikos (in Plato a shepherd wage-labourer who becomes a royal messenger, in Herodotus a favoured member of the palace guard) kills the king and succeeds to his power: the common factor to both versions is Kandaules' wife (another anonymous woman). Her seduction (if that is the right word) is a mere unobtrusive step in the story in Plato: the weird happenings-the earth quaking and opening, the bronze horse with little doors in its side, the huge corpse, the gold ring of invisibility-are already passed, the rest is matter of fact; and yet of course it is not-those other things had to happen to make it possible. In Herodotus the seduction is central: it follows instantly and it seems automatically upon an outrageous breach of the taboos of seclusion. ${ }^{118}$ The symmetry of outrage and revenge is brought out in the queen's orders to Gyges, to carry out his murderous attack on Kandaules 'from the same spot from which he displayed me, naked'. The story of Gyges clearly deals with the theme of the abnormal succession of male power through violation of the boundaries that

111 Od. $x 229$ ff., 310 ff. 348 ff.: cf. JHS xciii (1973) $91-4$.

${ }^{112}$ Dysk. 842 ff.; Perikeir. Iо 3 ff.; Sam. 726 ff.; fr. 682 Körte. Hdt. vi 130.2 (the marriage of Megakles and

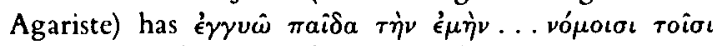

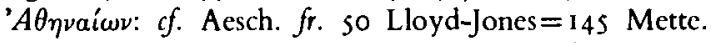
I 5-19; Nilsson, GGR i ${ }^{3}$ 120-2; Vernant, Mythe et Société (Paris 1974) $149 \mathrm{f}$.

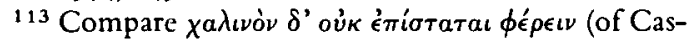
sandra, $A g$. 1066): in the context the dominant reference is to the yoke of slavery-but Cassandra is a virgin, and note

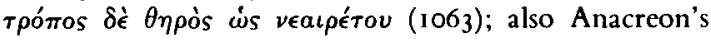
image of the filly and bridle: $P M G 417$.

114 Eur. Andr. 277 f.; cf. Tro. 924; Hel. 357; Hipp. I 148; fr. $357 \mathrm{~N}^{2}$. It is perhaps significant that at Sparta (but not at Athens) boys before their incorporation into the community as adults are referred to as members of 'herds' (of horses or cattle), requiring domestication: Plato, Laws ii 666e; C. Calame, Les chours de jeunes filles (Rome 1977) i 373-6; sec further ibid. $411-20$, on the metaphor of breaking in horses.

${ }^{115}$ Soph. O.T. I 485,1497 ff.; I257; I21 I f.: compare the rain of blood ( $1276 \mathrm{ff}$.), and the related image of the marriage-bed as harbour (420, 1208). Cf. also Ant. 569; J. Taillardat, Les Images d'Aristophane (Paris 1962) Io I nn. $1-2$. For agricultural imagery in the obscene metaphors of Old Comedy, see, e.g. Ar. Ach. 989 ff.; Jeffrey Henderson, The Maculate Muse (New Haven 1975) 45-7, 166-9. Henderson's distiction ( $8 \mathrm{f}$.) between 'grand' and obscene metaphor tends to obscure the underlying continuity of imagery.

116 Soph. Trach. 3I ff.

${ }_{117} \mathrm{Hdt}$. i 8-12; PI. Rep. ii 359c-360b. The parallelism of the two stories makes it unlikely that we should assume two different Gyges (so, e.g., Adam on Rep. ii $359 \mathrm{C}$ and his Appendix I on $\mathrm{t} 26 \mathrm{f}$. of his edn): in structural terms we have one story, and one hero. Burkert (Homo Necans 178-81) draws attention to parallels in Plato's version of the story with the Trojan Horse, the cult of Aphrodite Hetaira at Abydos, and Pelopidas assassination of the pro-Spartan polemarchs.

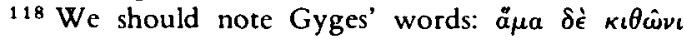

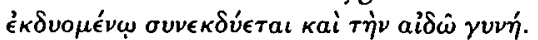


separate women from unrelated males (in the one version, through abnormal visibility; in the other, through abnormal invisibility).

My second story from Herodotus is in reality a pair of episodes whose interconnections are made explicit by Herodotus himself. The earlier of the two is narrated second and is set first in Attica, then Lemnos: it concerns the feud between the Athenians and the Pelasgian settlers on Lemnos. ${ }^{19}$ The story begins with the building of the Pelasgian wall around the Akropolis, the polis of Athenian tradition. The Pelasgians are rewarded with land, marginal land under the slopes of Mt Hymettos. The quarrel starts, in Hecataeus' version, over this land: under cultivation it becomes an object of jealousy and desire ( $\phi \theta$ óvos кai " $\mu \in \rho \rho s$ ) to the Athenians. In the Athenian account, the quarrel is over women: Pelasgian men and Athenian women encounter one another at the fountain Enneakrounos, and the result is rape, followed by a murderous plan against the men of Athens. The Athenians, in a striking deviation from the norms of such a tale, take no blood revenge but merely exile the Pelasgians, who remove to Lemnos. Exile, however, itself calls for revenge, and the Pelasgians descend on Brauron at a time designed to coincide with the festival of Artemis. They seize large numbers of the Athenian women who are gathered there to carry out the rituals of the goddess and take them back to Lemnos, where they become pallakai. The sons of these Athenian women speak Attic, and behave as Athenians: they will not mix with the sons of the Pelasgian women, they display complete solidarity in responding to insult or violence, and they establish superiority over the Pelasgian boys. If this is how they behave as children, the Pelasgians naturally ask themselves, how will they behave as grown men? The answer to this question issues in another act of violence: the Pelasgians kill all the Athenian-born boys, and their mothers. But the sons of Athenian women are also the sons of Pelasgian men and their murder brings about sterility in the earth, in women and in flocks. ${ }^{120}$ Delphi orders recompense to be made to Athens. The Athenians demand Lemnos, and they are promised it, upon fulfilment of an adynaton. When ('many years later', says Herodotus) Miltiades sails to Lemnos from the Chersonese in high summer, he claims that the adynaton is fulfilled, and against some scepticism makes good his claim by force. The astonishing richness of theme in this last story makes comment difficult, but perhaps unnecessary. It deals, evidently, with ambiguous questions of legitimacy and inheritance, with the mysterious and dangerous 'otherness' of women; it suggests interchangeability of women and land, of exile, rape and death, even of women and slaves; ${ }^{121}$ it touches on the establishment of cities (the Akropolis wall), and communities (the settlement of Lemnos), on life-giving fountains and rough land made good by agriculture, on kinship solidarity and feud, on sterility as the outcome of some misreading of the boundaries separating strangers from kin. In it women are seen as linked with the sacred, as necessary to the continuity of society and disruptive of it, the victims and the cause of violence and bloodshed.

The second episode takes place at Sparta and involves the 'grandsons' ( $\pi a i \delta \omega \nu \pi a \hat{i} \delta \epsilon s)$ of the crew of the Argo, expelled from Lemnos by the same Pelasgians who raped the Athenian women from Brauron. ${ }^{122}$ It responds reciprocally to the first episode. In it the Minyan descendants of the Argo arrive above Sparta on Mt Taygetos and kindle fire. On enquiry by the Spartans, they explain their presence by declaring that they have 'returned to their fathers', and request a share of land and status. Moved by the presence of Castor and Pollux on the Argo, the Spartans agrec; Minyans and Spartans exchange women, and the Minyans are distributed among the Spartan tribes. Soon after, the Minyans demand a share in the Spartan kingship and behave insultingly to the Spartans: they are arrested and are due to be executed. But in the night fixed for their execution they are visited by their Spartan wives, who exchange clothes with them and allow them to escape in women's dress; whereupon they return to Taygetos until some are eventually persuaded to join the expedition to Thera and others seize land in Elis. This time we have to do with incoming males, agnatic kinsmen of the inhabitants, who detach the women, daughters of leading members of the community, from their loyalties through marriage, who dress as women

$119 \mathrm{Hdt}$. vi 137-40: Philochorus FGrH 100-I provides a rationalising account of the same episode: the Pelasgian exile has political causes, but their revenge is still the seizure of Athenian women from Brauron.

120 Compare the plague of Soph. O.T.

121 Even of women and slaves: the Athenian women go to the fountain because 'at that time neither the Athenians nor any other Greeks possessed slaves', Hdt. vi 137. 3 .

122 Hdt. iv 145 . I: once more there is a rationalising alternative version, this time in Plut. de mul. virt. 8 (Mor. $247 a-c)$ 
and threaten the community from the mountains. Women are seen as points of weakness in the solidarity of the community, and as forming strong and fast-wrought ties with incomers who are also subverters of order. ${ }^{123}$

My random set of data was, then, not quite random: it displays certain recurrent themes and anxieties, and through it we can begin to see, I think, that myth may significantly add depth to that sense of the woman's role in society that we have so far been able to reach. This is because it brings into view ambiguities, tensions and fears, deep-seated fears, which the norms of law and custom are intended to control and even suppress: myth in some sense contradicts the comfortable surface normality of the social structure defined by law and custom, and points to conflict at a deeper level within the dominant structure. But the significations of myth are implicit, halfhidden and disguised, and need to be disengaged and made articulate. Before I turn to some recent attempts to do this, I will add, by way of recapitulation, a stasimon from the Choephoroe, which is itself an attempt to articulate the role of women in myth.

The first stasimon of Choephoroe immediately precedes the first encounter of Orestes and Clytemnestra, of son and mother, male and female. ${ }^{124}$ Generically it belongs with the $\pi \circ \lambda \lambda \dot{a} \tau \dot{a}$ $\delta \epsilon i v a$ stasimon of Antigone but it takes a different course. The opening strophe alludes to the sources of terror and destruction, the $\delta \epsilon \iota \nu \dot{\alpha} \delta \epsilon \iota \mu a ́ \tau \omega \nu \alpha \tilde{\chi} \chi \eta$, that breed and swarm on earth, in the sea, and in the sky between. The antistrophe continues: but who could recount the aggressive pride of men, the passions and desires ( $\left.\epsilon_{\rho} \rho \tau \tau \epsilon\right)$ ) of women that recognise no bounds, 'that make

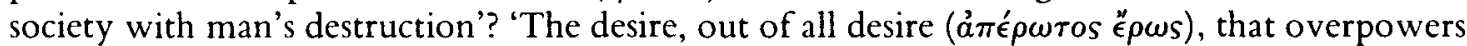
women' (or 'that gives women power' $[\theta \eta \lambda v \kappa \rho a \tau \eta \dot{ } s]:$ the ambiguity is revealing) 'defeats and

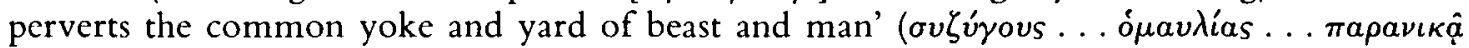
$\kappa \nu \omega \delta \alpha \dot{\alpha} \omega \nu \tau \epsilon \kappa a i \beta \rho \circ \tau \hat{\omega} \nu)$. The remaining strophic pairs recall the paradigms of myth: Althaia $(\dot{a}$

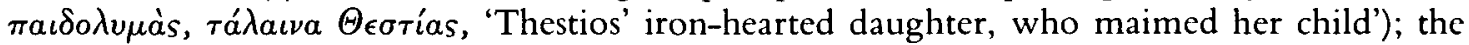
murderous Skylla ( $\dot{\alpha} \kappa v v o ́ \phi \rho \omega \nu$, 'minded like a bitch'), who destroyed a philos (her father) for the good of enemies; the women of Lemnos, and Clytemnestra herself. Meleager and Nisos were magically safe from death, until a mother and a daughter destroyed that magic; on Lemnos a

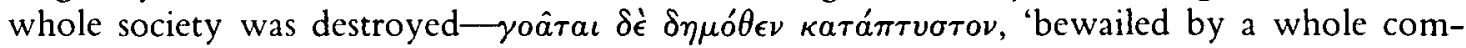
munity, detestable'-that is the ultimate paradigm of woman's evil. Men have their own unlimited and competitive aggression to fear, but they have to fear too the devious and consciously destructive sex of women, ${ }^{125}$ and what that brings is death.

So Aeschylus. The most interesting of recent attempts to disengage from myth its signification of the role of women in human society are those, on the one hand, of the French structuralist school of Vernant, Vidal-Naquet and Detienne, ${ }^{126}$ and on the other, of the American analytical psychologist Philip Slater. ${ }^{127}$ Methodologically they are poles apart, and it is therefore surprising and significant that they should have produced accounts which are recognisably similar in their general drift. What they point to, in the mythical imagination of Greece (and let us remind ourselves, for one last time, that we are speaking of the imagination of men), is a profound and ambivalent disquiet, an oscillation between obsessive fear and revulsion, on the one hand, and, on the other, an implication of total dependence. Women figure, with a quite extraordinary prominence, in Greek myth, but the roles that they play are shot through with implications of antagonism and ambivalence. Let me just list some obvious examples. The catalogue of women who figure as the destroyers of men, usually with marked sexual overtones, forms a long procession: Althaia, Skylla, Clytemnestra and the women of Lemnos ${ }^{128}$ we have already met in

${ }^{123}$ We should compare the Amazons in Herodotus' account of the origins of the Sauromatae (iv I I O-I 7): the theme of the breakdown of kinship solidarity brought about by women is prominent here too.

124 Aesch. Cho. $585 \mathrm{ff}$.

125 The stress on death consciously planned and designed is striking throughout: $\tau \dot{a} \nu . . \mu \eta \dot{\eta} \sigma a \tau o \pi u \rho \delta a \hat{\eta}$

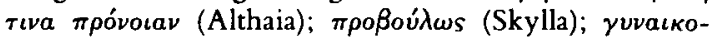

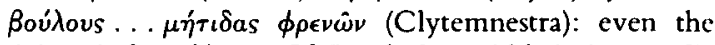
Erinys is $\beta$ voroó $\phi \rho \omega \nu$. Cf. Bacchyl. on Althaia (v $137 \mathrm{ff}$ ):

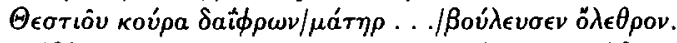

${ }^{26}$ See in particular Vernant, Mythe et pensée ${ }^{2}$ (Paris
I 965) 97-143; Mythe et Société 57-8 1, 1 77-94; DetienneVernant, Cumming Intelligence in Greek Culture and Society (Hassocks 1977) passim; Vidal-Naquet, 'Esclavage et gynécocratie dans la tradition, le mythe, l'utopie', in Recherches sur les structures sociales . . (n. 16) 63-80.

127 Slater, The Glory of Hera: Greek mythology and the Greek family (Boston 1968); see also Arethusa vii (1974) 9-44.

${ }^{128}$ On the Lemnian crime, see especially, Burkert $C Q$ $\mathrm{xx}$ (1970) 6-9, 15-16; Homo Necans 212-18; Dumézil, Le crime des Lemniennes (Paris 1924); Detienne, Jardins d'Adonis 172-84; Slater (n. 127) $164 \mathrm{f}$. 
Aeschylus. Without going far afield we can add Helen, Medea, Phaidra, Agaue, Stheneboia, Tyro, Eriphyle, Ino, Astydameia, Eidothea, the daughters of Danaos, of Proitos ${ }^{129}$ and of Minyas, ${ }^{130}$ even Deianeira; some, like Semele or Io or Europa, are destroyed by male divinities, some figure in both roles (Hekabe, even Helen); sometimes a pair of women act together as destroyer and destroyed, as Prokne and Philomela or as Hermione and Andromache in Euripides' play. Women act as 'rescuers' (Ariadne, Medea) or as 'rescued' (Andromeda); they are guarded and protected (as precious and vulnerable) but they are also imprisoned (as dangerous) - Danae, Antiope, Kleopatra; they are confined but they have longings for the wild (as Phaidra in Euripides' Hippolytus). ${ }^{131}$ Recurrently women act as the shacklers and inhibitors of men: Omphale perhaps springs first to mind, but Kakridis has recently pointed out how it is the role of the women of the Homeric poems to restrain and inhibit men from the assertion of their arete, ${ }^{132}$ and the inhibitory feeling of aidos is characteristically descriptive of encounters between men and women. ${ }^{133}$ The terrifying nightmare figures of Greek mythology-the Moirai, the Erinyes, Harpies, Graiai, Sirens, Skylla and Charybdis, Medusa and the Sphinx-and bogies of folklore, such as the $\mu \epsilon \iota \xi o \pi \alpha ́ \rho \theta \epsilon \nu o s$ (half woman, half snake) of Hdt. iv 9.I or she of Dio of Prusa v I2, are, again, characteristically women. ${ }^{134}$ The monstrous Minotaur is offspring of Pasiphae and an uncanny bull from the sea.

But it is the ambivalence of sex, and the uncertainties of femininity and of sexual roles which is perhaps most striking and interesting. Detienne has shown how an ambivalent attitude to sex is implicit not only in the rituals of the Thesmophoria and Adonia but also in such myths as those of Myrrha, Ixion and Phaon, as well as of Adonis himself. ${ }^{135}$ The ambiguity of a figure such as Helen is obvious, and we have already seen the polarisation of incompatible aspects of the female role in pairs of women such as Hermione and Andromache: this is a recurrent motif in Sophocles (the obvious examples are Antigone and Ismene, Electra and Chrysothemis; more ambiguously Deianeira and Iole) and it leads us, I think, to an instructive perception of how ambiguous, in Greek male imagination, is the masculine/feminine polarity. In one sense, it is the function of women in Greek society to define the male role by opposition: Pierre Vidal-Naquet and Simon Pembroke have made fascinating use of this opposition and its recurrence in Greek myth and tradition. ${ }^{136}$ Oedipus' words to Ismene in Oedipus at Colonus are a classic instance of the way in which the opposition male/female is seen as defining social structure. ${ }^{137}$ To call a man 'woman', as the chorus do to Aigisthos in Agamemnon, ${ }^{138}$ is the grossest insult and humiliation. But what of

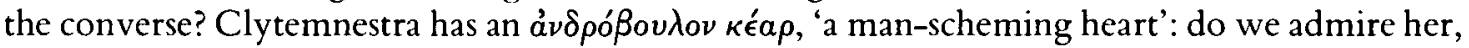
or fear her? ${ }^{139}$ When Orestes exclaims to Electra

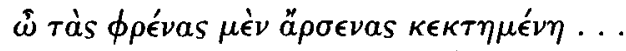

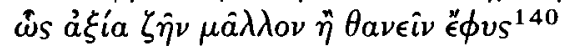

129 On the daughters of Proitos and the ritual of the Agrionia, Burkert, Homo Necans I 89-94: he sees its theme as that of women as monsters in revolt.

${ }^{130}$ On the daughters of Minyas, Burkert, Homo Necans 194-7. Again the myth is recalled in ritual, the Agrionia of Orchomenos (Plut. Quaest. gr. 299e-f): Burkert draws attention to the inverted symbolism of black and white in both myth and ritual.

${ }^{131}$ See the perceptive remarks of Lattimore, Arion i (1962) I 3 f. =Niall Rudd, ed., Essays...from Arion (Cambridge 1972) $27 \mathrm{f}$. We should compare the frustrations of Medea (Reckford [n. I s] $338 \mathrm{f}$.) and the 'escape' choruses of Euripides.

132 Kakridis, Homer revisited (Lund 197I) 68-75. The role of Poulydamas in $\mathrm{Il}$. xviii $249 \mathrm{ff}$. is comparable: thus not all 'inhibitors' are women.

133 See JHS xciii (1973) 87, n. 65; also n. 14 above.

134 Thalia Feldman, Arion iv (I 965 ) 484-94; Slater (n. I27) $63 \mathrm{ff}$. Again as has been pointed out to me, not all 'monsters' are female: Polyphemus, Geryon, Hades are male instances.

135 Detienne, Jardins d'Adonis 122 ff., I 48 ff. (Myrrha), $128 \mathrm{ff}$. (the myths of Phaon and Adonis), I6s ff. (Ixion), and for the rituals, above nn. 96, 97. The offspring of Ixion's attempted rape of Hera were the half-man, halfbeast Centaurs, on whom (which?) see Kirk (n. IOO) I $52-62$.

136 Vidal-Naquet (n. I26); Pembroke, 'Women in charge: the function of alternatives in early Greek tradition and the ancient idea of matriarchy' in J. Warburg $\mathcal{E}$ Courtauld xxx (1967) I-35; 'Locres et Tarente: le role des femmes dans la fondation de deux colonies grecques' in Annales (ESC) xxv (1970) 1240-70.

${ }^{137}$ Soph. O.C. 335 ff. The commentators cite the parallel at Hdt. ii 35.2 (weaving and staying at home as male roles): $c f$. the 'sick' overtones of Electra's words at Soph. El. 982 f. and Chrysothemis' reply at 997 . On sex differentiation as a theme of ancient Greek ethnography, see K. Trüdinger, Studien zur Gesch. der gr.-röm. Ethnographie (Diss. Basel I9 18) i 3 (Hecataeus), $31 \mathrm{f}$. (Herodotus).

${ }^{138}$ Aesch. Ag. I625: for parallels, see Wecklein and Fraenkel ad loc.

${ }^{139}$ On Clytemnestra's role in Agamemnon, see Fraenkel on $256 \mathrm{f}$., 609, I636; PCPS xxiv (1978) 58-60; F. Zeitlin, Arethusa xi (1978) i $52-60$.

${ }^{140}$ Eur. Or. $\mathrm{I} 2 \mathrm{O}_{4} \mathrm{ff}$. 
'Oh, the mind you have, it is a man's ...

your gifts deserve to live, not die!'

on a superficial reading the valuation is positive, but by now the whole action of Orestes has become ambiguous, not least the role of Orestes himself. Xenophon's Socrates is more straightforward; ${ }^{141}$ or is he? But the issue is wider than the mere explicit attribution of male characteristics to women. A friend recently described the impression made on her by the female figures of Euripides as one of 'men in drag'. In terms of literal theatre history that is, of course, true - and the fact itself is significant. But beyond that there is a discernible 'masculinisation' of women in Greek tragedy. Let me take just two indications of it. A defining trait of masculine competitive aggression is the horror of being humiliated by laughter and mockery and a determination to retaliate against even an imagined instance: Sophocles' Ajax and Philoctetes provide classic instances. ${ }^{142}$ But we should notice that the trait reappears in several of the women in tragedy: in the Erinyes of the Oresteia, in Medea, even in Antigone. ${ }^{143}$ Though she is a 'destroyer', Deianeira is, many would say, Sophocles' most 'feminine' character, but she dies by the sword: that is a horrifyingly masculine way to die, and the shock of it reverberates through the play. ${ }^{144}$ I have argued elsewhere that, in part, this 'masculinisation' of women is the consequence of theatre conditions and conventions: the inner life of the oikos is projected on to the public world of 'outside' and there are inevitable distortions of social role as a result. ${ }^{145}$ But that is not all. We have only to look at the motif of exchange of sexual roles and the recurrence of transvestism as a mythological (and ritual) theme, to see that it is not: Heracles and Omphale, Achilles on Skyros, Dionysus among the nymphs of Nysa, Pentheus himself. ${ }^{146}$ Indeed, the ambiguities of the myth and ritual of Dionysus are as much sexual as they are moral: Dionysus repeatedly taken for a woman, the Maenads descending on Hysiae and Erythrae like an army of men, the voyeurism of Pentheus. ${ }^{147} \mathrm{We}$ can add the sex-change myths of Teiresias and Kaineus. ${ }^{148}$

It emerges then from an examination of Greek myth that male attitudes to women, and to themselves in relation to women, are marked by tension, anxiety and fear. Women are not part of, do not belong easily in, the male ordered world of the 'civilised' community; they have to be accounted for in other terms, and they threaten continually to overturn its stability or subvert its continuity, to break out of the place assigned to them by their partial incorporation within it. ${ }^{149}$ Yet they are essential to it: they are producers and bestowers of wealth and children, the guarantors of due succession, ${ }^{150}$ the guardians of the oikos and its hearth. ${ }^{151}$ Men are their sons, ${ }^{152}$ and are brought up, as children, by them and among them. ${ }^{153}$ Like the earth and once-wild animals, they must be tamed and cultivated by men, but their 'wildness' will out.

The ambiguous correlation between women and the wild is not, of course, peculiar to Athenian or to ancient Greek culture at large. The tendency to categorise experience in terms of an opposition between 'culture' (what is accessible to and under the ordering control of human intelligence and human skills) and nature (what is 'outside', alien to human order and not subject

141 Xen. Oec. 10. I.

142 Soph. Ajax 367, 383, 454; cf. 79, 303,957, 961, 1043; Philoct. 258, 1023, 1125, 1235 .

143 Aesch. Eum. 789=819; Soph. Ant. 839 f.; Eur. Med. $38 \mathrm{I}-3,404,781 \mathrm{f}, 797,1049 \mathrm{f}$., 1060 f., 1354 f., I362: on the theme, see M. Shaw (n. 59) 26 i f.

144 Soph. Trach. 878 ff. (esp. 886 f., 89I, 898); 930 f.

145 PCPS xxiv (1978) $46,49-50$.

146 Slater (n. 127) 138 n. I, 287 ff., $378 \mathrm{f}$.

$147 \mathrm{Cf}$. Aesch. fr. 6I N $\mathrm{N}^{2}=72$ Mette; Eur. Bacch. passim, but esp. 453 ff., 493 ff., 748 ff., 81 I ff., 912 ff., I 202 ff., I 233 ff.; Slater (n. 127) 292 ff.; C. Segal, Arethusa xi (1978) 185-202. Compare the motif of voyeurism in the myth of Perseus: Slater 327.

148 Kirk (n. 100) 201; L. Brisson, Le mythe de Tirésias: essai d'analyse structurale (Leiden 1976) esp. $52 \mathrm{f}, 7_{73-7}$, 108-9 on the complex imagery of bisexuality, blindness and prophetic powers in the Tiresias myth.

${ }^{149}$ On rituals of incorporation and their significance, see JHS xciii (1973) 97 f.; Burkert, Homo Necans it f. and n. 16,74 f. and $n$. I 8 .

150 Notice the importance given by Herodotus to the role of Atossa-daughter of Cyrus, sister of Kambyses, wife of Dareius (esp. iii 88. 2-3)'; and mother of Xerxes (esp. vii 2.3-3.4); and to Mandane-daughter of Astyages, mother of Cyrus. Notice too Euphiletos' appeal to the jury to protect the rights of due succession against the threat of adultery: Lys. i 32-3.

${ }_{151}$ T. E. V. Pearce, Eranos lxxii (1974) 16-33, esp. 22-4, 3 I-2; Vernant, Mythe et pensée 97-I 43.

152 But equivocally: Apollo's denial of full parenthood

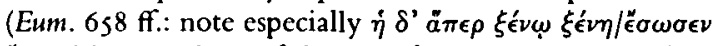

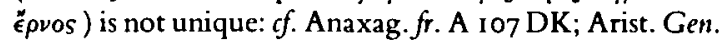
An. 765 b8 ff.; A. Peretti, Parola del Passato xi (1956) 241-62; Lebeck, The Oresteia (Washington D.C. 1971) 124-30 with nn. on $203 \mathrm{f}$.

${ }^{153}$ There is an interesting echo of the ambiguity of this situation in Men. Dysk. $3_{4} \mathrm{ff}$. 
to its control) has been widely documented by anthropologists. And in the terms of such an opposition, women, or certain facets of the social personality of women, are often seen (by men) as aligned with 'nature' rather than 'culture', or as 'liminal', existing in the dangerous no-man'sland between these mutually exclusive categories. Much of the symbolic transactions of social life, in many cultures, can be best understood as expressive of the 'liminality', or even the alienness, of women's existence. Ardener himself, for example, in the article from which I began this essay, went on to discuss myths and rituals of the Bakweri in the Cameroon which associate women with possession by the 'mermaids' of the rain-soaked forest, and to analyse the relationship between women and 'nature' implicit in these; and Bourdieu has analysed the complex symbolism of Kabyle social life in such a way as to underline similar associations. ${ }^{154}$ More recently Sherry Ortner has pointed to behavioural and psychological factors which tend, cross-culturally, to align women with 'nature' as against 'culture'. ${ }^{155}$ Moreover in the Greek context, the sharpness of the physical boundary between the enclosed world of house, high walls and narrow streets and the stark openness of the mountain beyond is a source of powerful imagery. ${ }^{156} \mathrm{We}$ have seen how, in terms of the categorisation of Athenian society, of the boundaries between inclusion and exclusion, women are 'boundary-crossers', anomalous beings who belong and do not belong, are 'within' and 'without'. And we have learnt from Mary Douglas how potent are the fears released by such anomalies to the dominant system of categorisation in any culture: 'all margins are dangerous... Any structure of ideas is vulnerable at its margins. ${ }^{1} 57$

The marginality of women may explain some aspects of their role in Athenian ritual. In so far as the gods are unambiguously seen as an extension of the dominant structure of socicty, that is, as analogous to (male) humans in motivation, behaviour, even appearance, then relationships with divinity may themselves be construed as an extension of human interaction, and be regulated according to the norms and categories of the (male) social order. But much in the imagery of Greek religion shows that this is not altogether so; that gods may be seen not as super-humans but as bestial; as 'natural', not 'cultural' powers; wild, not tamed. Divinity too is, potentially at least, anomalous: the divine powers are and are not part of the structure of 'social' relationships. ${ }^{158}$ Thus the contradictions that co-exist in the imagery of divinity are parallel to those that mark the social and ritual roles, and the mythical personality, of women, and the parallelism should have some explanatory value.

One of the most sustained attempts in Greek myth to order these contradictions is Hesiod's story of Prometheus and the creation of Pandora, brilliantly analysed in a recent paper by Vernant. ${ }^{159}$ Vernant has shown how the themes of the loss of bliss and ease, the creation by the gods of a new order, the present 'civilised' order of agriculture, animal sacrifice and fire, are

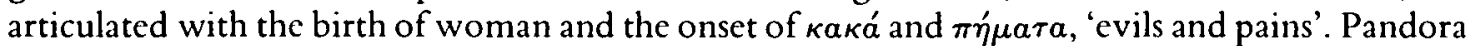
is beautiful; clothed and disguised by the skill of craft, she is a dolos that men will not be able to handle, ${ }^{160}$ a consumer of men, their sex, their strength and the food and wealth that their strength produces. But without her, society, the world as it is, cannot continue; and the world as it once was, without women, has been stolen and hidden by Zeus and cannot be stolen back: $\dot{\omega} s$ oúk $\tilde{\epsilon}_{\sigma} \sigma \iota$

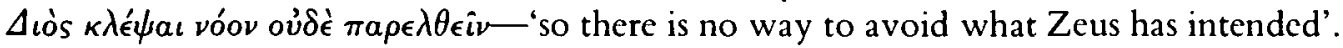

\section{CONCLUSion}

I have tried in this paper to show something of the true complexity of what we men summarize, brashly and arrogantly, as the social position of women, and to display the 'complementarity' of law, custom and myth as they can contribute to a fuller grasp of that complexity. I

\footnotetext{
154 See $n$. 165 below. Once more there is an analogy with the Sarakatsan association between men and sheep, on the one hand, and women and goats, with the distinctions in social role that result: Campbell (n. 53) 26, $31 \mathrm{f}$.

155 'Is Female to Male as Nature is to Culture?', in Rosaldo-Lamphere (n. 75) 67-87; $f$. Rosaldo, ibid. 1 7-42.

156 See, c.g., du Boulay (n. 52) 10-14, 36 f., $38 \mathrm{f}$.

157 Purity and Danger: an analysis of concepts of Pollution and Taboo (London 1966); quotation from p. 145 of the
}

Penguin edn.

${ }^{158}$ I hope to develop these points in a subsequent essay.

159 Vernant, Mythe et Sociêté, 177-94; sec also Kirk (n. 100) 226-38.

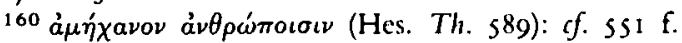

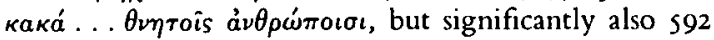

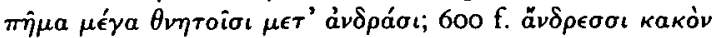

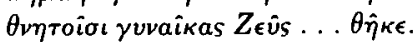


am conscious that I have only produced a preliminary sketch. The reason is as much my ignorance as the pressure of time and space. This is an enormous subject and there is still a vast amount of work to be done. I have not discussed such important things as philosophical and physiological traditions and theories about women; ${ }^{161}$ I have not pursued $\mathrm{Mr}$ de Ste Croix's important and far-reaching suggestion (which I would accept) that we should consider women in classical Athens as an exploited class, in the Marxist sense; ${ }^{162}$ I have not touched on a number of major Greek myths about women (for example, the Amazon myth); ${ }^{163}$ I have not even discussed the Funeral Speech and Ischomachus' wife. ${ }^{164}$ Above all, I have not been able to make adequate use of the great repository of relevant ethnographic material, or of the full range of theoretical discussion among anthropologists. ${ }^{165}$ For all these shortcomings I apologise. I would like to end by going back to Gomme. It was the stimulation of qualified disagreement with him that first set me thinking about this subject: I hope it will be clear how much I owe to him. He was right, of course, to make such full use of the evidence of myth and imaginative literature; but surely wrong to insist that everything there is perfectly familiar to us and unsurprising. He refers, among other things, to the significance of 'love' in the literature of Athens. When it is a matter of the 'happy ever after' endings of Menander's comic universe, we are on familiar ground, indeed, but Gomme also quotes Antigone: "E and there I want to say that Eros is not 'love', and that Gomme might have gone on to quote the rest of the chorus. The Eros of that chorus is an implacable antagonist in an all-out war; Eros 'falls on property' (as a destroyer); he who 'has eros' is out of his mind; eros warps the minds of the just

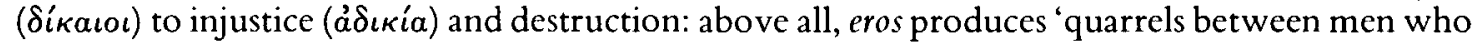

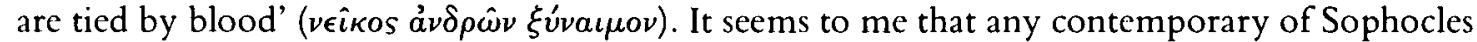
would have understood very well the bafflement of the Fingo elders when confronted with the impact of 'love' on things as they understood them. They were trying, in $\mathrm{I} 883$, to explain to the Cape Government Commissioners the sudden increase in illegitimate births and runaway marriages in their community, and they said: 'the trouble arises through a thing called love. We do not comprehend this at all ... This thing called love has been introduced.'

\section{University of Bristol}

JOHN GOULD

161 See especially Lloyd, Polarity and Analogy (Cambridge I 966) $48-51,58 \mathrm{f}, 348 \mathrm{f}$. etc.; Burkert, Lore and Science in Ancient Pythagoreanism (Cambridge Mass. 1972) $32-4,51-2,467-76$

162 In the second of his Cambridge J. H. Gray lectures, to be published as The Class Struggle in Ancient Greece.

${ }^{163}$ Prof. J. K. Davies has underlined for me the seriousness of this omission: a group of women on the margins of culture, whose weaponry, as mounted archers, defines them as opposite to males (hoplite panoply) and whose pretension to self-sufficiency as a society without males is 'paid for' by the loss of just that attribute which indicates their femininity and which is the sine qua non of a maternal role, they invade the territory of 'culture' and are defeated and ejected by Theseus, after Heracles has stolen their queen's girdle.

164 Thuc. ii 45. 2, on which see P. Walcot, Greek Peasants, Ancient and Modern (Manchester 1970) 71-5; Xen. Oec. vii $5-6$.

165 In particular, recent work on the symbolism of classification in traditional societies: as well as the work of Mary Douglas, see V. W. Turner, The Forest of Symbols (Ithaca 1970); Bourdieu's major theoretical study, Outline of a theory of practice (n. 3) and the articles of S. J. Tambiah, Ethnography viii (1969) 424-59, and R. Bulmer, Man ii (1967) 5-25, both repr. in M. Douglas, ed., Rules and Meanings (n. 72) 127-93. Edmund Leach, Culture and Communication (Cambridge 1976) may serve as an introduction to this work.

166 Gomme (n. 4) I 13. 